Portland State University

PDXScholar

Dissertations and Theses

Dissertations and Theses

$5-1-1969$

\title{
Aspects of the Åland Islands question
}

Elen Christine Sakshaug

Portland State University

Follow this and additional works at: https://pdxscholar.library.pdx.edu/open_access_etds Let us know how access to this document benefits you.

\section{Recommended Citation}

Sakshaug, Elen Christine, "Aspects of the Åland Islands question" (1969). Dissertations and Theses. Paper 745.

https://doi.org/10.15760/etd.745

This Thesis is brought to you for free and open access. It has been accepted for inclusion in Dissertations and Theses by an authorized administrator of PDXScholar. Please contact us if we can make this document more accessible: pdxscholar@pdx.edu. 
AN ABSTRACT OF THE THESIS OF Elen Christine Sakshaug for the Master of Arts in Teaching presented May 1, 1969.

Title: Aspects of the $\AA$ land Islands Question

APPROVED BY MEMBERS OF THE THESIS COMMITTEE:

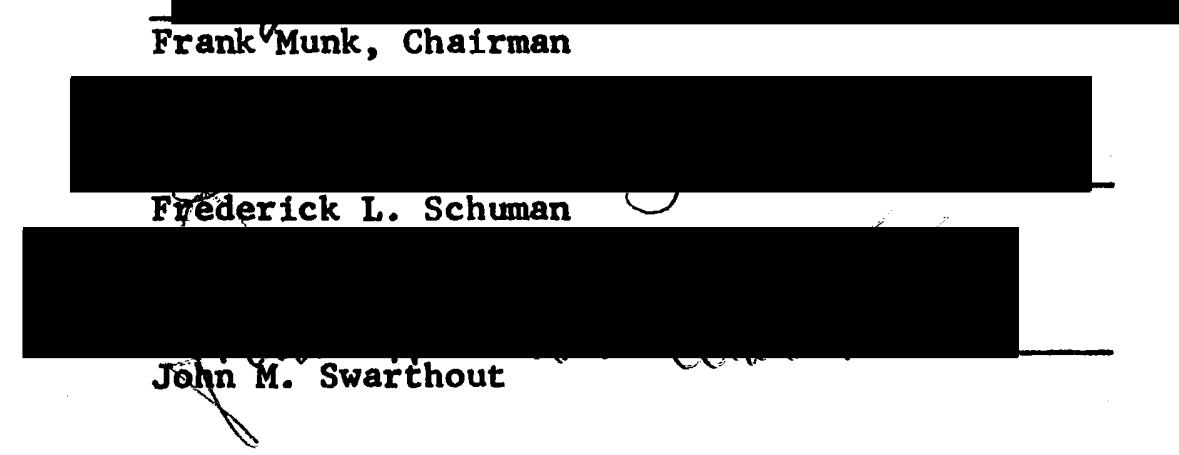

The Aland Islands question in international politics has been intermittently discussed, negotiated, and settled since the eighteenth century.

The Islands lie in the Baltic Sea, halfway between Sweden and Finland, at the mouth of the Gulf of Bothnia. They have been accorded importance by international dispute and finally by international treaty. In the present thesis the position of the Aland Islands in the Scandinavian region, from the time of settlement to the present, is considered. Major events and agreements are included to provide a background for the development of the dispute which arose over the Islands in the early twentieth century.

Upon close investigation, the $\AA$ land Islands question is found to be composed of a number of elements, among which are the issues of 
territorial sovereignty and claim, neutralization, demilitarization, ambitions of self-determination, minority rights, and the mechanics of settlement in a post-war climate. All of those factors combined to compose the dispute over the Islands between Sweden and Finland, which was settled in 1921, and which has remained in relative quiescence since that time.

In the period since 1921, the Islands with their Swedish-speaking population have constituted a special autonomous province in the Republic of Finland. The Islands in the mid-twentieth century are a kind of showcase for workable autonomy.

The purpose of this thesis is to consider the factors which determined the final settlement of the question and to examine the area from the vantage point of forty-eight years later.

The main approaches in the thesis are in the areas of history, international politics, international law, and domestic politics. These are not mutually exclusive; rather they are recurring foci in the development of the Aland Islands question. By these foci an attempt has been made to explore and describe the position of the $\AA_{1 \text { and }}$ Islands today, based on what has gone before, nationally, regionally, and internationa1ly. 


\section{ASPECTS OF THE ÅLAND ISLANDS QUESTION}

by

\section{ELEN CHRISTINE SAKSHAUG}

A thesis submitted in partial fulfillment of the requirements for the degree of

MASTER OF ARTS

in

TEACHING

Portland State University

1969 
TO THE OFFICE OF GRADUATE STUDIES

The members of the Committee approve the thesis of Elen

Christine Sakshaug presented May 1, 1969.

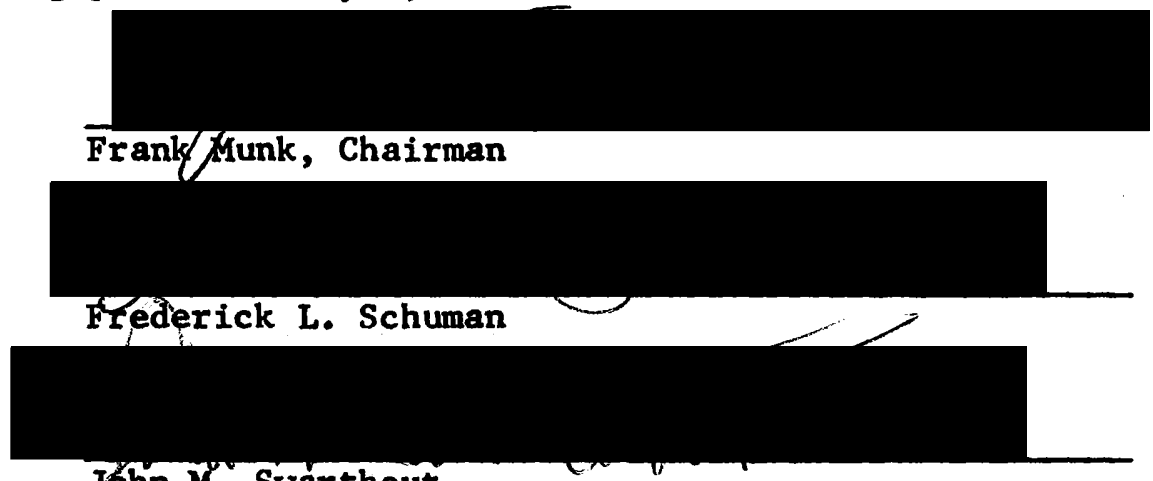

John M. Swar thout

APPROVED:

Howard E. Dean, Head, Department of Political Science

Cbarf R. MaXcolm, Acting Dean of Graduate Studies

May_ 16, 1969

今 


\section{ACKNOWLEDGMENTS}

The writer wishes to express her deep appreciation to her thesis advisor, Dr. Frank Munk, for his interest, patience, and guidance throughout the preparation of the thesis.

Also the writer is very grateful for material provided by Lauri Hannikainen, Attache, of the Embassy of Finland, Washington, D.C., Raimo Salmi, Acting Consul General, of the Consulate General of Finland, San Francisco, California, and by Matts Dreijer, Landskapsarkeologen, \&lands Museum, Mariehamn, Finland.

Thanks are due as well to the Interlibrary Loan Office at Portland State University which was able to procure sources not available in the inmediate area, without which the research could never have been completed. 
TABLE OF CONTENTS

PAGE

ACKNOWLEDGMENTS . . . . . . . . . . . . . . . . . ili

LIST OF FIGURES . . . . . . . . . . . . . . . . . . v v

CHAPTER

I INTRODUCTION . . . . . . . . . . . . . . 1

Geography . . . . . . . . . . . . .

II SWEDISH POSSESSION OF THE

ALAND ISLANDS .................. 6

III FINLAND AND THE \&LAND ISLANDS

IN THE RUSSIAN EMPIRE: $1809-1917 \ldots . . . . . . .14$

IV TNTERNATIONAL DISPUTE OVER THE

ALAND ISLANDS: $1917-1920$. . . . . . . . . . 30

$\checkmark$ THE \&IAND QUESTION BEFORE THE LEAGUE

OF NATIONS COUNCIL: $1920-1921$.......... 45

VI THE CONFERENCE IN GENEVA: 1921... . . . . . . . 58

VII THE Aland ISLANDS SINCE 1921 . . . . . . . . . 69

VIII CONCLUSIONS ................... 81

A LIST OF WORKS CONSULTED . . . . . . . . . . . . . . . 89 
LIST OF FIGURES

\section{FIGURE}

1. Map of the $\AA$ land Islands, 1854 . . . . . . . . . . 86

2. Map of the Approaches to the Aland Islands.................. 87

3. Map of the Aland Islands, showing the Zone borders revised in the 1939 Stockholm P1an . . . . . . . . . . . 88 
CHAPTER I

\section{INTRODUCTION}

The Aland Is lands have been accorded importance by international dispute and finally by international treaty. That alone could serve as reason enough to consider them subject amenable to and suitable for study.

Upon close investigation, the Aland Islands question is found to be composed of a number of elements including the issues of territorial sovereignty and claim, demilitarization, neutralization, ambitions of self-determination, minority rights, and the mechanics of settlement in a post-war climate. All of those combined in varying degrees in the dispute over the Islands between Finland and Sweden which was settled in 1921, and which has remained in relative quiescence since that time.

The aspects of the Aland Islands question considered in this thesis touch the areas of history, international politics, international law, and domestic politics.

The purpose of the thesis is to consider events leading to the dispute over the Islands and the factors determining the final settlement of the question.

The thesis deals as well with measures taken by the Finnish government to assure the preservation of the Swedish nationality of the 
population of the Aland Islands, after the dispute was settled in 1921 through the Council of the League of Nations.

The questions of non-fortification, demilitarization, and neutralization constitute continuous factors in the Aland Islands question; they are important aspects of the question both internationally and nationally.

\section{GEOGRAPHY}

Geographically the Aland Islands constitute the westernmost part of the Finnish Republic. They are a group of eighty inhabited islands in addition to approximately 6,000 other identifiable islands and rocky reefs. The largest island is Fasta Aland, from which the Islands take their name.

The Island group is situated directly at the entrance to the Gulf of Bothnia, twenty five miles from the East Central coast of Sweden, and about forty-five miles Southwest of the Finnish mainland. The strait between the Easternmost Aland Islands and the mainland of Finland is known as the "Skiftet;" it contains many small islands and rocky reefs as well as shallow water which freezes over readily during the winter months.

The relationship of the Aland Is lands to Finland geographically is most clearly seen in the winter months when it is not unusual for the Islands to be linked to the Finnish mainland by ice.

officially the Aland Islands zone is described as lying between $59^{\circ} 27^{\prime}$ and $60^{\circ} 41^{\prime}$ North Latitude with the easternmost point being $21^{\circ} 20^{\prime}$ East Longitude from Greenwich and the westernmost point being 
$19^{\circ} 05^{\prime}$ East Longitude from Greenwich. ${ }^{1}$

The Islands themselves are not blessed with abundant natural resources. It has been the position rather than the prosperity of the Islands that has dictated their inclusion in disputes among the major Baltic powers.

As far as physical description is concerned, the Islands are composed of bedrock, primarily granite, which is topped by depositional features of marine and glacial origin. The total area is some 581 square miles. It is the smallest of the nine counties of Finland.

For its latitudinal position, vegetation is quite varied, including such trees as pine, spruce, and birch, as well as lesser amounts of alder, oak, hazel, and maple. The crops on the Islands also reflect the relatively mild climate; they include spring and autumn wheat, oats, barley, potatoes, rape, onions, cucumbers, and beets.

In 1919 the population of the Aland Islands was approximately 22,000 inhabitants. 2 In the official 1960 census, the population numbered $20,981 .^{3}$ At the end of 1966 the population was 21,500 persons. Officially a Swedish-speaking province of Finland, the inhabitants are mostly seamen, fishermen, and farmers. Some workshop industry

1"Convention relative à la non-fortification et à la neutralisation des îles d'Aland," J.0. Söderhjelm, Démilitarisation et neutralisation des îles d'Aland en 1856 et 1921 (Helsingfors, 1928), p. 372 . Appendix.

2 John Wuorinen, A History of Finland (New York: Columbia University Press, 1965), p. 294.

3"Ahvenanmaa," Encyclopaedia Britannica, 1968 e., Vo1. I, p. 413.

4Matts Dreijer, Glimpses of Aland History (Mariehamn, Finland:
Alands Tidnings-Tryckeri Ab., 1968), p. 47. 
exists, where farm and forest products are processed. Traditionally the Alanders have been famous for their ship building and for sailing feats in the days of the grain races from Australia to Europe. Now the merchant tonnage from Åland is twenty-five percent of the total merchant fleet of Finland. 5

Because of the strategic location of the Aland Islands the interests of Sweden, Russia, and Finland have focused on the Islands in several disputes over whose lake the Baltic should be. The ramifications of Baltic confrontations among Baltic powers were not confined solely to the Baltic area.

Germany, Great Britain, and to a lesser extent, France also reacted when the question of Baltic control arose. In the case of Great Britain, the commerce in timber from northern Sweden shipped via the Aland Sea has been a continuous factor in her interest in the Aland Islands. Both Germany and Great Britain have been concerned with the same route for the shipment of iron ore from the Gulf of Bothnia.

In the Dictionnaire universel d'Histoire et de GEographie, published in 1861, the following description of the Aland Islands is given:

Aland (1'archipel d'), dans la mer Baltique à l'entrée du golfe de Bothnie. Jadis à la Suede, appartient à la Russie depuis 1809. Il a une haute importance politique et militaire, -L ile d'Aland proprement dite a $39 \mathrm{k}$. sur $31 ; 13,000 \mathrm{~h}$. Occupée en 1854 par les Franģais. 6

The Aland Islands, "Ahvenanmaa" in Finnish, as steppingstones between Finland and Sweden have been affected by several international

5Dreijer, Glimpses, p. 47.

6M.N. Bouillet, Dictionnaire universel d'Histoire et de Géographie (Paris: Hachette, 1861), p. 30 . 
agreements and treaties. The most important ones have been the Treaty of Nystad, 1721; the Treaty of Frederikshamn, 1809; the Treaty of Paris, 1856; and the Convention for the Demilitarization and Neutralization of the Aland Islands, 1921.

Since approximately the eleventh century A.D. the Aland Islands have been in the hands of Sweden, Russia, and Finland, in that order. Swedish control of the Islands is the era first to consider. 
SWEDISH POSSESSION OF THE ÅLAND ISLANDS

The beginning of Swedish possession of Finland and the Aland Islands is usually dated at 1155-1157 A.D., when a crusade led by King Erik IX, the patron saint of Sweden, rendered the Finns converts to Christianity and established the Finnish area as a Swedish domain. ${ }^{1}$ However, a study of medieval graves has shown that Christian burial practices existed in Finland at least a century before the alleged crusade. $^{2}$ According to the historian, Jackson,

Christianity was known in the Aland Islands and modern Finnish historians believe that it was not unknown on the mainland; they suggest that Eric's crusade was prompted by an appeal from baptized Finns to save them from persecution by the pagans. 3

Later publications indicate that the $\stackrel{\circ}{1}$ and Islands were indeed an area of contact between Swedish and Finnish culture in prehistoric times. "The Aland Islands had a development of their own during the prehistoric period. Lying halfway between Finland and Sweden they were subject to influences from both. ${ }^{4}$

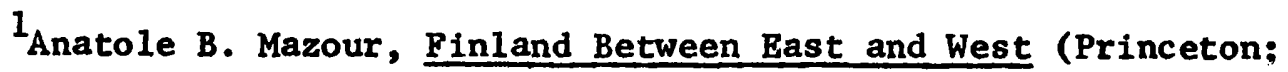
D. Van Nostrand Company, Inc., 1956), p. 3 .

2 John H. Wuorinen, Scandinavia (Englewood Cliffs: Prentice-Hal1 Inc., 1965), p. 19.

${ }^{3}$ J. Hampden Jackson, Finland (New York: The MacMillan Company, 1940), p. 28 .

${ }^{4}$ El1a Kivikoski, Finland, trans. Alan Binns (New York: Frederick A. Praeger, 1967), p. 8 . 
Early pottery in the Aland Islands was clearly brought by people from southwest Finland, indicating settlement from that area. Similarity of pottery and idols indicates obvious connection with the mainland. Pottery from the later part of the Stone Age and from the Bronze Age gives evidence that the settlement was a continuous one. ${ }^{5}$ Connections with Finland seem never to have been broken, even with the introduction of population from the west (Sweden) after 2000 B.C. 6

The long period following the Bronze Age in Aland, lasting until approximately the sixth century A.D. is characterized by few archeological finds and what objects have been found cannot be exactly dated. The Iron Age in Aland dates roughly from 500 to 1000 A.D. During the later part of this period the "Viking" era shows Swedish influences on the Aland Islands. "As far as one can see at present, Aland during the Viking period was part of central Sweden, and the hoard finds with their Arabic silver coins underlie this connection with . . central Sweden."7

After 1000 A.D. there was an absence of heathen burial suggesting that Christianity was present by the eleventh century A.D. With the advent of Christianity the historic period for the Aland Islands begins, as does increased contact with Sweden.

The history of the Aland Islands between 1157 and 1809 remains to be adequately documented. But mention is made of the Islands in several instances during that time, and Swedish control of the Islands is understood.

5 Kivikoski, Finland, p. 55.

${ }^{6}$ Ibid.

${ }^{7}$ Ibid., pp. 132, 133. 
By 1284 Finland, including the Aland Islands, constituted a Duchy in the Swedish realm. By the Peace of Nöteborg, 1323, the boundaries between Finland and the principality of Novgorod were defined, and Swedish control of Finland was said to be complete. 8

In 1362 the Finns were admitted to take part in the election to the Swedish throne. Finnish representatives were sent to the election of Swedish kings until the monarchy ceased to be elective and became hereditary in 1544. Finland was considered one of the län (provinces) of Sweden.

One remarkable aspect of Swedish occupation in Finland during the first centuries was the lack of extreme coercion. Part of the reason a strong Swedish rule was not established in Finland was the lack of centralization within the Swedish state at that time. Finland; as one of the $\underline{1 a ̈ n}$, was not treated as a conquered province; tribal divisions obeyed their own laws. 9 And local administration was left to the pikkalaiset, or local councils of the peasant aristocracy. 10

Notable Swedish-Finnish conflict did not occur partly because Finland had no strong central administration to overcome, and the Finnish area itself offered no temptation for concentrated economic exploitation. In addition, there were no marked differences in the social development of the two people.

For approximately five centuries Finland preserved a certain unity

${ }^{8}$ Great Britain, Foreign Office Historical Section Handbooks, The Aland Islands (London: H.M. Stationery Office, 1920), p. 9.

${ }^{9}$ Great Britain, The Aland Islands, p. 13. 10 Jackson, Finland, p. 29. 
of its own with a remarkable degree of local autonomy; in 1581 Finland became a Grand Duchy as an integral part of the Swedish Dominion.

The exact conditions prevailing on the $\AA$ land Islands are not precisely recorded. According to one historian the Aland Islands constituted a separate fief of the Crown during the Middle Ages; and in 1569 they were a dower-state for the Swedish Queen-Dowager Catherine. ${ }^{11}$ It has also been proposed that before 1634 the Islands formed a "territory and sometimes a government apart [from the Finnish 1 än, A Abo]". 12

According to M. Sjaestedt,

For long periods the archipelago had a separate governor, who resided in the fortress of Kastelholm and depended directly on the prefecture of Stockholm. From the ecclesiastical point of view, the archipelago . . . formed part of the diocese of Upsa1 a. 13

Later the Islands seem to have been combined with Finland for administrative purposes. In 1556 King Gustavus I awarded the Duchy of Finland, including the Aland Islands, to his son, John.

A separate Diet for the Grand Duchy of Finland was established by King Gustavus II Adolphus during his reign, 1611-1632. The Finnish Diet contained representatives of the four estates -- nobles, clergy, burghers, and peasants, as in Sweden. 15

Under the Swedish Constitution of 1634, by which the kingdom was

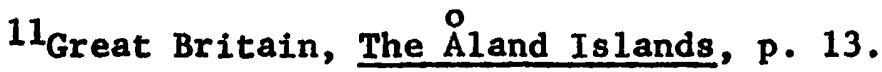

12 Ibid.

13 Ibid., pp. 13, 14 .

${ }^{14}$ Jackson, Finland, p. 36 .

15Hugh Shearman, Finland: The Adventures of a Sma11 Power (New York: Frederick Praeger, Inc. 1950), p. 10. 
officially divided into provinces, the Aland Islands are noted as forming part of the Government of Abo, Finland; they were also at that time subject to the archbisphoric of Abo as well. 16

The location of the Islands has assured their inclusion in armed disputes between competing Baltic powers. Both Russia and Sweden clashed over control of the Baltic littoral.

In 1714 the Aland Islands were occupied for the first time by Russian troops in the Great Northern War. ${ }^{17}$ Later, in 1718, negotiators from both Sweden and Russia met on Aland to draw up a draft treaty; the essence of the agreement was that Sweden should cede her Baltic provinces conquered by Russia, to Russia. In return, Sweden would receive the cooperation of the Tsar in obtaining territorial compensation from the other countries who were aligned against Sweden. 18

The treaty was never solidified. Finally the Peace Treaty of Nystad, August 30,1721, was concluded between Russia and Sweden. Sweden ceded to Russia the provinces of Livonia, Estonia, Ingria, the city and district of Viborg, and the islands of Oesel and Dagö, along with a part of Karelia. Russia returned the whole of Finland (excepting the ceded Karelian area) and the Aland Islands to Sweden. The Aland Islands were not specifically mentioned in the treaty.

Sa Majesté Czarienne s'engage en échange et promet de restituer et évacuer à sa Majesté et à la Couronne de Suede . . . .

${ }^{16}$ Great Britain, The $\AA$ land Islands, p. 14 .

17 Michael T. Florinsky, Russia: A History and an Interpretation, Vol. I (New York: The MacMillan Company, 1966), p. 345.

$$
18 \text { Ibid., p. } 350 \text {. }
$$


le grand Duché de Finlande, excepté la partie qui en a été réservée ci-dessous dans le Règlement des Limites, laquelle apartiendra à Sa Majesté Czarienne. 19

Russia gained further Finnish territory during the war of 17411743, ended by the Treaty of Abo in 1743. The Russian-Swedish clash of 1788-1790 brought no change in territory, but by $1808-1809$ the Russians had gained the upper hand on the eastern side of the Baltic.

By March 1808 Russia occupied Finland, and Finland was considered "province russe" in the Russian Empire. By March 1809, Russian troops crossed the ice and occupied the Aland Islands. From there the troops crossed the frozen Aland Sea to Grisslehamn Sweden, not far from Stockholm. The orders of the Russian Tsar were to take Stockholm, but the Russian troops retreated to Aland due to the fragility of the ice. 20 With Russian troops occupying both Finland and the Islands, peace negotiations between Russia and Sweden were initiated at Frederikshamn.

The negotiations there were marked by Swedish demands to put distance between the Russian acquisitions and the Swedish mainland. On her part, Russia demanded that Sweden cede all of Finland and the $\AA$ land Islands. The Swedish delegates sought to convince the Russian delegates that Swedish security was an object of the peace and that it could not be achieved by Russian possession of the Aland Islands (Sweden having previously ceded territory in the interest of the security of St. Petersburg).

${ }^{19}$ Dumont, Corps Universel Diplomatique, Vo1. VIII, Part II, p. 36, quoted in Great Britain, The Aland Is lands, p. 15.

20J.0. Söderhjelm, Démilitarisation et neutralisation des $\hat{1}$ les d'Aland en 1856 et 1921 (Helsingfors, 1928), p. 85. 
The Russian delegate emphasized

that the Aland Islands were indispensable to the defense of Finland, and that after the conquest of the Aland Islands Russia would not aspire to increase her territory at the expense of Sweden, that the Islands belong to Finland if for no other reason than the bridge of ice that connected them with the continent during four months of the year, and that besides it was not a question of Finnish frontiers, but those of Russia. 21

Realizing that Russia would not cede the $₫$ land Islands, the Swedes could only hope that "l'appétit de la Russie serait satisfait." 22 Some final efforts were made by the Swedes; they requested that Russia agree not to establish any fortifications nor establish any naval base on the Islands. The other plan was to oblige France to guarantee the integrity of Sweden as a compensation for Sweden's reduced security resulting from the loss of the Islands. ${ }^{23}$ Russia declared any such restriction "humiliante" and Finland, including the Aland Islands, was ceded to Russia by the Treaty of Frederikshamn, September 17, 1809. The importance attached to the Islands by the Swedes can be noted in the dispatch sent to Stockholm by Skjöldebrand, the Swedish delegate to the conference at Frederikshamn:

Les îles d'Aland sont la clé de Stockholm et de toute la suède. Par cette possession, que les Russes ne manqueront pas de fortifier, ils pourront nous dicter 1 a loi neme en temps de paix. Il vaut mieux mourrir les armes a la main que conclure une paix qui nous rendra esclaves des tyrans du Nord. 24

In contrast to the 1721 Treaty of Nystad, the Treaty signed in

${ }^{21}$ söderhjelm, Démilitarisation et neutralisation des ̂̂les d'Aland, p. 87, translated.

22 Ibid.

${ }^{23}$ Ibid., pp. $87,88$.

${ }^{24}$ Ibid., pp. $88,89$. 


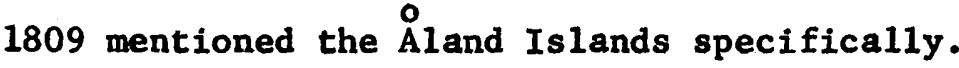

Article IV. -- Sa Majesté le Roi de Suède . . . renonce - . en faveur de S.M. I'Empereur de toutes les Russes.. - à tous ses droits et titres sur les Gouvernements ci-après spécifiés, qui ont été conquis par les armes de Sa Majesté Impériale dans la présente guerre sur la Couronne de Sulede; savoir les Gouvernements Kymenegärd [sic] de Nyland et Tavastehus, d'Abo et Biorneborg avec les Iles d'Aland, de Savolax et Carelie, de Wasa d'Uleaborg, et de la partie de Westrobothnie jusqu'à la riviére de Tornéa, comme il sera fixé dans 1 'article suivant sur la démarcation des frontières. . . .

Article V. -- La mer d'Aland (Alando Haf), le Golfe de Bothnie, et les rivieres de Tornéa et de Muonio, formeront dorénavant la frontière entre l'Empire de Russie et le Royaume de Suède. . . .

A distance égale des côtes, les $̂ 1$ es les plus rapprochées de la terre ferme d'Aland et de la Finlande appartiendront à la Russie, et $\grave{a}$ la Suede celles qui avoisinent ses côtes. 25

With Finland a Grand Duchy in the Empire of Russia, the question of fortification on the Aland Islands, introduced by the Swedes at the conference of Frederikshamn, became a continuing factor in the development of the $\AA$ land question.

${ }^{25}$ Martens, Nouveau recueil de traités (Gottingue: Librarie de Dieterich, 1817), pp. 23, 24, quoted in Great Britain, Foreign Office Historical Section Handbooks, The Aland Islands (London: H.M. Stationery Office, 1920), p. 16 . 
FINLAND AND THE ÅLAND ISLANDS IN THE RUSSIAN EMPIRE: 1809-1917

The era of Finland as an autonomous Grand Duchy in the Russian Empire has been variously interpreted as a time of Finnish self-awakening, and a period of legal autonomy in an empire not otherwise deemed "constitutional." Actually, the roles of the Tsar himself, and the governmental structure in Finland were not clearly defined in Finland. 1 And the position of Finland within the framework of the Russian Empire was not clear either. 2

As an example, the Tsar Alexander I, in a manifesto on March 15, 1809,

confirmed and certified the religion, fundamental laws, rights and privileges which each estate in the duchy, in particular, and all the subjects residing therein, from the lowest to the highegt, had enjoyed in the past according to their constitution. 3

Finland in 1809 was made up of provinces held by Russia since 1721, merged in 1809 with greater Finland which had been a Swedish province for some five centuries. In 1811, the area ceded to Russia in 1743 was merged with Finland. Obviously, the provinces held by Russia since 1721 were not subject to the same laws as were the western parts of Finland.

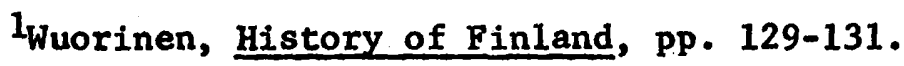

2Florinsky, Russia, p. 703.

3. Ibid. 
"Fundamental laws" previously applied were hardly applicable in 1809 if only due to their extreme variety. Swedish laws had been changed between 1721 and 1809. Most notable of the changes in Swedish law were the two acts which essentially amounted to a new Constitution for the kingdom; in 1772 the Form of Government was passed, creating a kind of balance between the Diet and the monarch, and increasing the king's power over the provisions of the 1634 Basic law. In 1789 the Act of Union and Security was passed, giving the Swedish king exclusive power to call the Diet into session, and to initiate legislation. 4 It is to those Acts that the Tsar Alexander I referred, but they had not been uniformly applicable to the whole Grand Duchy he called "Finland." Finland, before 1809, had not had her own executive, and the central governmental institutions in the Duchy after 1809 were not provided for by Swedish Law; the Diet was not called to session until 1863. The nineteenth century in Finland saw the development of national pride in Finland, as a separate entity. Tsar Nicholas I, who succeeded Alexander $I$, in 1825 imposed strict censorship on the Finns, the result being a literary revival. In 1835 a collection of folk songs and tales was combined into an epic poem called the Kalevala. The collectorwriter was a Swedo-Finn, named Lönnrot. The Kalevala, though not a factual history, provided the Finnish speaking people with a sense of individual national background, something that the common Finn lacked due to the predominance of Swedish-speaking Finns in the society. 5

${ }^{4}$ Raye R. Platt, ed., Finland and Its Geography (New York: Duel1, Sloan and Pearce, 1955), pp. 14-17.

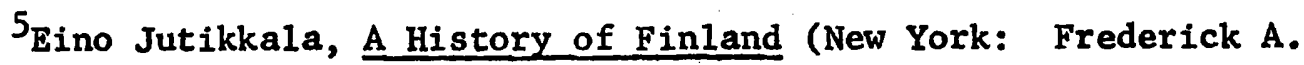
Praeger, 1962), p. 205. 
Another writer connected with the emergence of nationalism was A. I. Arwidssen, who summed up his sentiments in the following words, "Swedes we are not; Russians we can never be; therefore we must be Finns." 6

Pressure grew for education in the Finnish language in Finland; in 1863, Tsar Alexander II issued an edict designed to place the Finnish language on an equal status with Swedish by the end of a twenty year period. By 1894, Finnish was made the alternative language in the Senate of Finland.

With the accession of Tsar Nicholas II, in 1894, a period of intense "russification" began. The Tsar sent Governor-General Bobrikov to Finland, to carry out repressive measures restricting freedom of speech, assembly, and press; provisional governors were replaced by Russians, and the Finnish army was deactivated. Governor-General Bobrikov was assasinated in 1904 by a Finn.

The period at the turn of the century was one of increasing resistance to "russification," and gradually the working class asserted itself in the form of a Labor Party in 1899, to be called the Social Democratic Party in 1903. They were able to solidify to some extent when the Russo-Japanese War took some of the pressure from Finland. The Social Democrats called a successful general strike in 1905; immediately following, the Tsar accepted a manifesto which demanded that previous rights be restored to the Diet, and a new system of universal suffrage for elections be initiated.

${ }^{6}$ Platt, Finland and Its Geography, p. 18. 
Elections were held in Finland, in 1907, with the Social Democrats winning two-fifths of the seats in the Diet. Bills were passed restoring the right of free speech, assembly, and press, providing compulsory education for children between the ages of seven to thirteen years, and reducing the industrial working day to nine hours. The effects of those bills were not long lasting.

By 1910, the Russian Duma passed an act forbidding the Finnish Diet to legislate on such domestic matters. "Russification" was continued until the Finns declared their independence.

In the final independence movement, three Acts are significant in the progression to independence from Russia. In July of 1917, the Finnish Diet passed a bill by which it assumed all powers that had been held by the Grand Duke, excepting foreign affairs and defense; those were to be left to the Russian provisional government. That provisional government refused to recognize the right of the Diet to pass such legislation; it declared the Diet dissolved, and called for new elections .

New elections were held, and by an Act of November 15, 1917 the Finnish Diet "proclaimed its right to assume supreme power under the Constitution of $1772 .{ }^{7}$

On December 6, 1917 Independence from Russia was declared. By December 31, the Bolshevik leaders had signed a document accepting the right of the Finnish Diet to make such a declaration. On January 4, 1918, Russia formally recognized Finland as an independent country; recognitions immediately followed from Sweden, France, Germany, Denmark

${ }^{7}$ P1att, Finland and Its Geography, p. 25. 
and Norway.

Civil War in Finland came on the heels of the Declaration of Independence. The numerous Russian troops stationed in Finland for military purposes, and to aid in the work force, were not recalled to Russia; they remained in Finland and along with the workers formed the "Red Guards". The "White Guards" initially formed of university students and independent groups to protect life and property, fought to drive the Russians out of Finland.

Under the brilliant leadership of General Karl Gustav Mannerheim, the "Whites" together with the battalion of Prussian-trained Jaegers and Swedish volunteers, aided by 12,000 German troops placed under General Mannerheim's command, routed the "Reds" from their last strongho1d. Finland's Independence was thus assured by May of 1918 . While nationalism, "russification", and the independence movement were currents inside Finland as a Grand Duchy in the Russian Em-

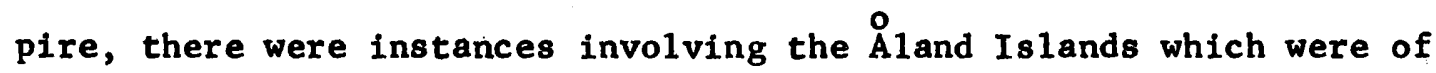
international importance. Since the Islands were strongly Swedish in language and culture, the process of "russification" probably was not as keenly felt there. They were of direct strategic value to the Tsar and his Empire. Thus the Aland Islands were subject to actions taken by Russia and the other great powers in the years from 1809 to 1917. Russia, being fully aware of the strategic importance of the Aland Islands on her western border, began construction of fortifications on the largest island not long after the Islands were ceded to her. The question of fortifications, to reappear periodically after 1809, was a point on which British interests coincided with Swedish interests in maintaining free access to the Gulf of Bothnia via the 
o

Aland Sea. The result was that in 1815 the British government made "representations" to the Russian government about the undesirability o of fortifications on Aland, and construction was subsequently discon8

tinued. The proposed fortifications were located at Bomarsund, on o Aland; the location was assumed by the British to be chosen with offensive naval plans in mind, rather than the defense of the Finnish mainland.

By 1834, Russia was again building fortifications at Bomarsund, and though the British warned Sweden of the danger of such Russian fortifications, Sweden replied by expressing confidence in Russia (a sign of Swedish desire to not become involved in the event of a British-Russian clash). Swedish foreign policy was taking on a neutral cast. Russia maintained her fortifications at Bomarsund, which by the start of the Crimean War in 1853 were formidable. Those fortifications at Bomarsund were destroyed during the course of the war in 1854 by an Anglo-French force, assisted by the British Baltic Squadron commanded by Admiral Sir Charles Napier, ${ }^{9}$ hence the mention in Chapter I of French occupation on Aland Island in 1854.

Sweden's King Oscar I resisted overtures by Britain and France to join allied forces against Russia in the war. King Oscar was unwilling to make commitments without guarantees from the allies; he declared that Sweden would consider entrance into the war only after Austria had declared herself. 10 Even after the conquest of Bomarsund the

${ }^{8}$ Söderhjelm, p. 90.

9 James Barros, The Aland Islands Question: Its Settlement by the League of Nations (New Haven: Yale University Press, 1968), p. 5.

10 Ibid. 
French proposed Swedish occupation of the Islands, to which King Oscar I replied that as long as conditions necessitating a break with Russia were not existing, Sweden could not occupy the Islands. 11

Refusal to occupy the Islands did not mean a lack of Swedish interest in them. On June 3,1855, Lord Palmerston was approached by the Swedish Minister in London who emphasized that in future peace arrangements, it would be important not only for Sweden but for Europe, if the Aland Islands were restored to Sweden, or at least that sufficient guarantee would be given against reconstruction of the fortifications which had been destroyed during the war.

By November, 1855, an agreement was reached between Sweden and the allies, Britain and France. Sweden, fearing Russian annexation of Gotland and invasion in the North, made tentative plans to enter the war. The exact intent of the treaty of November 21, 1855 was that Sweden-Norway would cede none of her territory nor any rights (fishery or pasturage) to it, to Russia, and France and England would guarantee the territorial integrity of Sweden-Norway. ${ }^{13}$ It was not a treaty of alliance; Sweden undertook no obligation to support Britain or France if they were subject to attack from Russia.

Hostilities ceased before Sweden actively entered the Crimean conflict. Her arrangement with the allies prior to the conclusion of hostilities put Sweden in an advantageous position to press for protection of her interests in the Baltic. Even before peace negotiations

$11_{\text {Söderhjelm, p. } 93 .}$

${ }^{12}$ Ibid.

${ }^{13}$ Ibid., p. 94 . 
officially were begun, King Oscar I addressed a personal letter to Napoléon III, listing Swedish "desiderata"; they included: limitations of Russian naval forces in the Baltic Sea and the White Sea, restitution of the Aland Islands to Sweden or neutralization under the collective guarantee of France, England, and Sweden-Norway, and prevention of Russian fortifications on the Finnish coast West and North of Sveaborg. 14 By the end of January, 1856, it became clear that the Aland Islands were indeed a topic for consideration at the Paris negotiations. From London, the Danish Minister for Foreign Affairs reported Lord Clarendon as saying that Russian agreement not to reconstruct the fortress at Bomarsund should be considered a condition sine qua non of the peace. $^{15}$ At the same time, a defeated Russia gave notice that prohibition to reconstruct the fortress at Bomarsund would not in itself be an obstacle to the peace.

Negotiations opened in Paris on February 25, 1856; the Swedish Envoy, Manderström, found that although Britain supported Swedish demands, the French were already committed to a policy of rapprochement with Russia, ${ }^{16}$ and were thus less sympathetic to Swedish Baltic ambitions. Manderström presented three alternative proposals dealing with the Aland Islands. (1) The restitution of the Aland Islands to Sweden; (2) the neutralization of the Islands as an independent state under the protection of France, England, and Sweden-Norway, or under

\section{${ }^{14}$ söderhjelm, p. 96.}

${ }^{15}$ Ibid., quoting Bojer, Nordens, saerlig Danmarks Neutralitet under Krimkrigen (Köbenhaven: 1914), p. 689 .

$$
{ }^{16} \text { Barros, p. } 8 \text {. }
$$


Sweden-Norway alone; (3) military neutralization of the Islands. 17

Britain's Lord Clarendon proposed to Count Orloff, one of the Russian Delegates, that Finland and the Aland Islands be restored to Sweden; the proposal was refused. Without active French support, Britain and Sweden were obliged to limit their demands to demilitarization and non-fortification of the Islands. Russia clearly considered the Islands essential to the defense of Finland and she was unwilling to relinquish her sovereignty over them.

Prior to the Crimean War, British-Swedish commercial interests in timber shipping became so well established that Britain had an active interest in who controlled the approaches to the Gulf of Bothnia. While Russian control of the Islands was unsatisfactory, fortification of the Islands would have been intolerable. So, the possibility of demilitarization and non-fortification was the most acceptable alternative for both Sweden and Britain, given the Russian intransigence and the lack of active French support. Russia agreed to the demilitarization and non-fortification of the Islands on March I, 1856.

The British Delegate, Lord Clarendon, and the two Austrian Delegates, Count Charles Buol, and Hübner, wished to have the Convention on the demilitarization and non-fortification of the Aland Islands, annexed to the general treaty of peace ending the Crimean War. Count Walewski, the French Foreign Minister, did not support the proposal, nor did the two Russian Delegates, Count Orloff, and Baron von Brunnow. They wished to have a separate act concluded among the powers which took part in the war in the Baltic theatre. Faced with the Austro-

$$
17 \text { Söderhjelm, p. } 97 .
$$


British combination, Orloff conceded. The Convention was signed on March 30, 1856 and was annexed to the Treaty of Paris as Article Thirty-three. The delegates at the Paris Conference realized that the Convention regarding the Aland Islands would gain force by annexation to the general peace treaty. Count Buol and Lord Clarendon wished the convention annexed "au point de vue européen," and the Russians understandably wished a separate convention without "caractère européen."

By Article Thirty-three of the Peace of Paris, the demilitarization and non-fortification of the Islands was achieved, a demand first made by Sweden in 1809. The first article of the Annex III to Article Thirty-three of the 1856 Treaty reads as follows:

Sa Majesté IÉmpereur de toutes les Russies pour répondre au désir qui lui a été exprimé par Leurs Majestés 1 'Empereur des Français et 1a Reine du Royaume-Uni de la Grande-Bretagne et d'Irlande, déclare que les $\uparrow$ les d'Aland ne, seront pas fortifiées et qui' 1 n'y sera maintenu ni créé aucun établissement militaire ou naval. 18

The signatories to the Convention were Britain, France, and Russia; Sweden was not one of the signatories, nor was mention made of Sweden in the Convention, but the Convention obviously increased the security of her East Coast. At the same time the arrangements concluded in Paris guaranteed relatively stable conditions that remained in effect for the following fifty years. After the Treaty of Paris, Napolkon III is quoted as saying to a Swedish representative in Paris:

Je Pense que le Roi a lieu d'être content. L'effet moral est atteint et c'était 1à l'essentiel. Obtenir davantage eût été impossible, sans compromettre de grands intérêts et peut être même la paix qu'il nous fallait. Les Russes ne peuvent avoir aucun établissement militiare là, ne peuvent pas non plus y ré-

18

söderhjelm, p. 341. 
unir des troupes. I'attention de $I^{\prime}$ Europe est maintenant attachée sur ce point; on en connaft l'importance; on ne la négligera plus. - - - La Russie n'y porterait pas deux régiments sans mettre I'Europe entière en émoi; vous êtes délivrés de cette forteresse qui était à la fois une insulte et une menace. 19

The Aland question remained in quiescence for fifty years following the 1856 Convention, as part of the Treaty of Paris.

Attention was focused once again on the Islands in 1906 when Iswolsky, the Russian foreign Minister, attempted to bring the Aland question up for reconsideration. With the 1905 dissolution of the Swedish-Norwegian Union, the November 21, 1855 Treaty of Guarantee between Sweden-Norway, Britain, and France was abrogated. Iswolsky believed that with the change in nature of the Swedish kingdom, the status of the Scandinavian peninsula established by treaties during and following the Crimean War could be renegotiated. His purpose was to seek release for Russia from the declaration of non-fortification of the Aland Islands in 1856.

Russian failure in the Far East brought renewed focus to her Western borders and the prohibition applying to the Aland Islands. Thus, in 1906, Russian troops were sent to the Islands, naval units were sent to patrol the waters of the Islands, and a wireless station was established on $\AA$ land on the pretext of checking gun running by Finnish nationalists. Russia justified the measures taken on the grounds that internal disorders necessitated them. Though the Russian measures were discussed in the British House of Commons, no formal protest was issued from either London or Paris. The garrison was

${ }^{19}$ Söderhjelm, p. 117 quoting sjöstedt, La question des ̂̂les d'Aland: un problème Baltique (Paris, 1919), p. 19. 
withdrawn in October, 1906.

The fact that questions had been raised over possible changes in the Islands' status, did not deter Iswolsky from his intention to abrogate the Convention of 1856 . To that end, he requested German support of his plan. A secret protocol was signed on October 29, 1907, in which Germany agreed not to object to the abrogation of the 1856 Convention. Germany, however, was not a signatory to the 1856 Convention, and technically the permissions of both France and Britain were required for a change in the status of the Aland Islands, by abrogation. France gave no objection to Iswolsky's plan; Norway, anxious to have. her independence and territorial integrity guaranteed by a new treaty, was eager to have British support for the abrogation of the 1856 Convention. 21

Britain did not officially object to a change in the Convention, but at the same time she did not wish to leave Sweden in an isolated position. Sir Edward Grey believed that any change in the status of 0 the Aland Islands or the Baltic area should be handled by a conference of interested states. Sweden was understandably opposed to Iswolsky's plan.

Iswolsky then tried another angle; he hoped to arrange an understanding between Russia, Germany, and Sweden, by which the 1856 agreement could be abrogated. It was another inept move on his part, since it involved two non-signatory powers to the 1856 Convention. Once his

$$
\begin{aligned}
& 20 \text { Barros, p. } 13 . \\
& 21 \text { Ibid., p. } 14 .
\end{aligned}
$$


plans were made public, there was an outcry in both Sweden and Britain. Finally realizing that pressure for a change in the status of the Aland Islands immediately following the Anglo-Russian Convention of August, 1907, was unwise, Iswolsky had to content himself with a Baltic Declaration in 1908 which affirmed the status quo in the Baltic area.

The Declaration was signed by Germany, Russia, Denmark, and Sweden. The Baltic Declaration in no way affected the 1856 Convention already in force, and Britain and France were not signatories to the 1908 Declaration. Iswolsky had achieved nothing; Russia was not legally released from the 1856 Convention. In 1909 Iswolsky was removed from his position as Foreign Minister.

Between 1908 and 1915, Russia gave repeated assurances to Sweden that she had no intention of converting the Aland Islands into an advance base against Sweden. The new Russian Foreign Minister, Sazonov, was well aware of the danger that if Sweden felt menaced she would seek protection from Germany. That being understood, the Russians still found it necessary to reconsider her assurances given, after the outbreak of the First World War.

Sweden's declared neutrality in the first months of the War were influenced by warnings from London, Paris, and St. Petersburg, that the Triple Entente would be "freed from all obligations" toward Sweden if she sided with Germany. The Swedish Prime Minister in 1914, Knut Hjalmar Hammarskjöld leaned toward the German side. Also, Norway, and Denmark did not intend to become involved in the conflict. Sir Esme Howard, the British Minister to Stockholm, recorded the German offer of 22 Barros, p. 15 . 
Finland restored to Sweden if Sweden would side with Germany. The Swedish Foreign Minister, Herr Wallenburg, declined the offer. ${ }^{23}$ In January, 1915 a suggestion was made from Stockholm to Berlin that the Aland Islands be neutralized for the duration of the war, assuming that the Russians would agree to the plan. Germany rejected the suggestion from a position of strength, her Baltic fleet being larger than that of Russia.

Russia, fearing German attempts to occupy the Islands, decided to fortify them. The threat of German control of the approaches to the Gulf of Bothnia, and of German U-boats and naval vessels operating from a key Baltic base dictated the Russian decision. Russia was not anxious to cause agitation in Stockholm, and so warned the Swedish government confidentially, in advance, that defensive measures would be taken in the Aland Islands for the duration of the "present hostilities." Sweden responded by agreeing to the Russian measures and noted that safeguarding maritime commerce between the two nations was welcomed by the Swedish government.

The text of the communiqué to Sweden from Russia on January 8 , 1915, reads as follows:

Le Governement Impérial me charge de faire à Votre Excellence 1a communication suivante: Le Gouvernment Russe croit savoir que la flotte allemande profitant de la prochaine congélation du skägord d'Aland aurait 1 'intention d'occuper 1 'archipel $d^{\prime} A l a n d$ afin de $s^{\prime}$ en servir come base d'opérations contre les côtes du Golfe Finois et aussi pour empêcher tout trafic maritime entre la Russie et la Suède. Dans le but de contrecarrer ce projet d'attaque et pour assurer autant que possible la navigation commerciale entre 1a Russie et la Suède dans le Golfe de Bothnique, les autorités russes prennent des mesures particulières pour $1 a$ défense de 1'archipel d'Aland. Le Gouverne-

${ }^{23}$ Sir Esme Howard, The Theatre of Life: Life Seen from the Stalls, 1903-1936 (Boston: Little, Brown, and Company, 1936), p. 220. 
ment Impérial croit de son devoir d'en prévenir le Gouvernement Royal d'une façon strictement confidentielle, en appuyant sur le fait que toutes ces mesures ont un caractère exclusivement défensif et pour le temps de la guerre. Le Gouvernement: Impérial espere que si, malgré le strict secret dans lequel sont prises ces mesures elles étaient quand même ébruitées, le Gouvernement Royal s'emploirerait à calmer l'opinion publique suédoise au sujet du caractère des mesures précités et des intentions exclusivement defensives du Gouvernement Russe. 24

There was uneasiness in Sweden in 1915 over the lack of provision in the Russian assurances for demilitarization of the Aland Islands after the war. Sweden was anxious that the restrictions imposed by the 1856 servitude would again be observed. Not being a signatory to that agreement, she had no legal position to call for observance of the servitude.

Finally, in May, 1916, Sweden accepted the Anglo-French statement composed with Russia's consent, concerning the fortifications on the o Aland Is lands.

Les Ministeres de France et d'Angleterre sont autorisés à confirmer les assurances anterieurement donnés au Gouvernement Royal par le Ministre de Russie et $\bar{a}$ déclarer que leurs Gouvernements respectifs ont également reçu du Gouvernement Imper ial $1^{\prime}$ assurance que les mesures aux quelles la Russie a dû recourir dans les îles d'Aland ont un caractere exclusivement défensif et n'ont été prises que pour la durée de la guerre. 25

No mention was made of the 1856 agreement, but it is accepted that the agreement was not considered abrogated; the signatories did not declare it so upon approving temporary Russian fortifications. The demolition of those fortifications remained a great concern for Sweden, and was later handled by a treaty agreement between Finland, Sweden, and Germany.

$$
\begin{aligned}
& 24 \text { Barros, p. } 345 . \\
& 25 \text { Ibid., p. } 346 .
\end{aligned}
$$


From 1809 to 1917 the status of the Aland Islands was determined by the interests of the great powers -- Russia, France, and Britain, who also helped to define Swedish interests in the Baltic area. The question became more tangled during the First World War and immediately following, during the peace negotiations.

Currents of national feeling aroused in Finland resulted by 1917 in the declaration of independence from Russia, and a civil war; while self-determination inspired the Finns, it also inspired the Alanders who were ethnically Swedish.

The position of the Aland Islands during the period of Russian control of Finland is most obviously defined by the International Convention of 1856. After the First World War, the position of the Aland Islands was again defined by the great powers, but the actors were not all the same as in the Crimean War era. It is to the development of the $\stackrel{\circ}{1}$ and question with $\stackrel{\circ}{\mathrm{l}}$ anders and independent Finland as participants that attention must now be turned. 
INTERNATIONAL DISPUTE OVER THE ÅLAND ISLANDS: 1917-1920

By 1917 it was evident that unrest existed on the Aland Islands, and that for the first time, the voices of the Alanders would be heard.

During World War I, the soldiers of the Russian garrison on the Islands had been hard on the Alanders. After the Russian Revolution, the situation became worse; the population was subjected to molestation and pillaging by undisciplined Russian soldiers.

As an alternative to the maltreatment they received as part of the Russian Grand Duchy of Finland, the Alanders thought to ask for reunion with Sweden. The population of the Islands was overwhelmingly Swedish in language and outlook; although the Swedish dialect spoken on Aland was the same as that spoken in the Turku archipelago, there was no other such uniformly Swedish-speaking area on the Finnish mainland. Most of the Islands' trade was with Sweden. 2

If the people of $\AA$ land were to choose between becoming part of an independent Finland or attempting to reunite with Sweden, the latter would have been their obvious choice. From the perspective of August, 1917, the future of Finland looked uncertain; whereas Sweden appeared

1J.0. Söderhjelm, Démilitarisation et neutralisation des îles d'Aland en 1856 et 1921 (Helsingfors, 1928), p. 144.

- ${ }^{2}$ Great Britain, Foreign Office Historical Section Handbooks, The Aland Islands (London, H.M. Stationery Office, 1920, p. 31. 
stable, settled and sympathetic to the wishes of the Alanders. The population of the Islands was not part of the mainstream of the Finnish independence movement; in fact, the situation on the mainland appeared to be one of anarchy and hopelessness when viewed from the Islands.

On August 20, 1917, collective action toward self-determination and union with Sweden was taken. A communal assembly was held on Aland to consider reunion with Sweden. Four representatives were chosen to 0 convey the Alanders' desire for incorporation in the Kingdom of Sweden to the Swedish government. That delegation with its requests never reached Sweden, but word of it did.

Four months later, a plebiscite was held on the Islands from December 25 to 29,1917 . In that plebiscite, ninety-five percent of the adult male and female inhabitants voted for reunion with Sweden. 3 An appeal, dated December 31, 1917, was written to the King of Sweden; the appeal was signed by 7,135 inhabitants; ${ }^{4}$ it stressed the hope that the Islands could be reunited with Sweden, and that a solution could be achieved with the assent of an independent Finland. 5 The appeal did not reach Stockholm until February 2, 1918, by which time Sweden had already recognized independent Finland.

In replying to the Alanders the King noted that the hope expressed by the Alanders for a solution in accord with Finland was considered by him to be the best course.

3Great Britain, p. 21.

${ }^{4}$ Ibid.

5söderhjelm, p. 145 . 
In November, 1917, previous to the appeal by the Alanders to Sweden, Germany had offered to occupy the Aland Islands. Once that had been accomplished, the Islands were to be handed over to Sweden and occupied by Swedish troops, with the understanding that they would not be turned over to any other power. 6

The King, with his ministers present, heard the secret overture and noted that the offer was not compatible with Swedish neutrality. If Sweden were to have occupied the Islands, it would have amounted to a casus belli with Russia and the Entente. It was in some ways parallel to the Swedish refusal to occupy the Islands in 1854.

The collapse of Russia made the Baltic area a safer place in which to maneuver, for Sweden, and the appeals of the Alanders reinforced the arguments for Swedish possession of the Islands for strategic reasons as well as in support of the principle of self-determination. At the same time, the indications were that independent Finland intended to keep the Aland Islands. Sweden was aware of Finland's geopolitical value, and was also aware that the Aland Islands in the hands of a friendly buffer state would be more advantageous to Sweden than a hostile Finland who had lost part of her territory.

Russian negotiations with the Central Powers prompted King Gustaf $V$ of Sweden to address a note on December 23, 1917, to the governments of Germany, Austria-Hungary, and Turkey, requesting that the Aland Islands question should be considered at Brest-Litovsk in order that Swedish interests could be safeguarded. The plan to send a Swedish

6ames Barros, The Aland Island Question: Its Settlement by the League of Nations (New Haven: Yale University Press, 1968), p. 61 . 
delegate to Brest-Litovsk was not approved by the Entente representatives in Stockholm. That a representative of neutral Sweden should meet with the enemies of the Entente and one of its allies (Russia), to discuss a question affecting Finland (not represented) seemed improper; moreover, it would involve only some of the powers who were signatories to the 1856 Convention.

Sweden was not finally invited to Brest-Litovsk, but the $\AA$ land Islands were included in the treaty. On March 3, 1918, the Treaty of Brest-Litovsk was signed. The following paragraphs were contained in Article VII of the Treaty:

Finland and the Aaland Islands will immediately be cleared of the Russian Red Guard, and the Finnish ports of the Russian fleet and of the Russian naval forces. So long as the ice prevents the transfer of warships into Russian ports, only limited forces will remain on board the warships. Russia is to put an end to all agitation or propaganda against the Government or the public institutions of Finland.

The fortresses built on the Aaland Islands are to be removed as soon as possible. As regards the permanent non-fortification of these islands as well as their further treatment in respect to military and technical navigation matters, a special agreement is to be concluded between Germany, Finland, Russia, and Sweden; there exists an understanding to the effect that, upon Germany's desire, still other countries bordering upon the Baltic Sea would be consulted in this matter. 7

Following the Brest-Litovsk Treaty, a Finno-German Treaty was signed on March 7, 1918, declaring that a state of war did not exist between Finland and Germany. A German promise to help obtain general recognition of Finnish independence was coupled with a promise by Finland "not to cede any territory to a foreign power, nor to grant any

7C.J. Smith, Finland and the Russian Revolution, 1917-1922 (Athens, Georgia: University of Georgia Press, 1958), p. 45, quoting Jane Degras, ed., Soviet Documents on Foreign Policy, I, 54. 
servitude to a foreign power without German permission." A final article of that treaty dealt with the fortifications on the Aland Islands.

The contracting parties are agreed that the forts built upon the Aland Islands are to be removed as soon as possible, and the permanent non-fortified character of these islands and also their treatment in a military and technical sense for purposes of shipping, shall be settled by agreement between Germany, Finland, Russia, and Sweden; and to these agreements, at the wish of Germany, the other states bordering upon the Baltic Sea shall be invited to assent. 8

After the Alander delegation had departed Stockholm, the Swedish Foreign Minister, Hellner, received reports of anarchic behavior of Russian soldiers on $\stackrel{\circ}{A}$ and, and pleas of the population for help and protection. 9 By February 13, 1918, Sweden had unilaterally dispatched a military expedition to the Islands, allegedly to protect Swedes there, and to evacuate any Finns and Swedes who wished to leave. Russian troops were then fighting soldiers of the White Guards who had arrived on the Islands. The Swedish forces halted the fighting and disarmed the White Guards, sending them back to Finland, via Sweden and northern Finland. The Russian leave-taking continued until March 15, when it was speeded by the arrival of German troops en route to aid General Mannerheim's forces in the civil war.

Swedish troops left the Islands by May 16, 1918, by which time the Finnish civil and military authorities were in control on the Finnish mainland.

Russia had protested military measures taken on the Islands, noting that unless the Swedish troops were withdrawn, the operation "Peace".

${ }^{8}$ Smith, quoting U.S. Department of State, Texts of the Finland

${ }^{9}$ Barros, The Aland Is lands Question, p. 78 . 
would be considered as hostilities against the Russian Republic; Sweden discounted Russian threats at that point, owing to the conditions of exhaustion and revolution in Russia. Russia was about to negotiate the Brest-Litovsk Treaty by that time.

Once Finland was free of the bolshevik threat, having been recognized as independent by Russia, there were immediate problems of constItution-making, government organization, and recovery from the effects of the civil war. There remained also, the treaty negotiations which were concluded with Russia in 1920.

In the months following the end of the Finnish civil war, the Aland dispute became acute. Sweden and Germany were still concerned over the fortifications remaining on the Aland Islands. By December 30 , 1918, an accord concerning the demolition of the fortifications and other military establishments on the Islands was concluded. It was ratified by Sweden, Finland, and Germany on March 29, 1919.10 A control commission of officers from the contracting states observed the demolition process which was begun on April 1, 1919, and completed by October 1919. Russia was not consulted as provided by the March FinnoGerman Treaty.

By the time the December 30, Treaty had been concluded, the war in Europe was over, and the question of the disposition of the o Aland Islands remained unresolved. Sweden was willing to submit the question and advocated that the future of the Islands be settled by a plebiscite on the Islands, the results of which would be binding on both Finland and Sweden. The Finnish position regarding the plan for a plebiscite was that it would be unjustified since the $\AA$ landers ${ }^{10}$ Söderhjelm, p. 134 . 
comprised only a small part of the total Swedish-speaking population of Finland. To grant a group of people that size the right of self-determination was a reductio ad absurdum of the principle of self-determination.

In addition, one aspect of Swedish policy must have been aggravating for the Finns; Sweden had given diplomatic recognition to Finland, in January of 1918, with no conditions attached, thus tacitly admitting that the Aland Islands were indeed a part of Finland. Then, for Sweden to make an issue of the Alanders' temporary discontent, seemed unnecessary to the Finns.

On June 7, 1918, representatives of the various communes on Aland met together to form a representative assembly on the Islands. That assembly, or Landsting, as it was known, addressed requests to the Governments of France, the United States, Great Britain, and Italy, on November 9, 1918, via their missions in Stockholm. The requests asked that the question of the Aland Islands be considered at the peace conference, and that a plebiscite based on the principles of self-determination would be used to decide their fate, to be binding on both Sweden and Finland. The same request was sent to the Finnish government, and a negative reply was given. 11

Even after General Mannerheim had met with King Gustav V, no agreement was reached between Finland and Sweden as to how the question should be resolved. The Swedish view was that either two plebiscites be taken on the Islands, or that both Finland and Sweden refer the question to the Paris Peace Conference for decision. Finland, on the

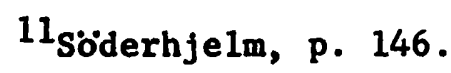


other side, considered the matter a domestic one, not suitable for treatment by the Paris Peace Conference.

On February 13, 1919, Crown Prince Gustav of Sweden called on Lord Curzon in London, who was then the interim Foreign Secretary. Grown Prince Gustav expressed concern that if Russia were to acquire Finland and the Aland Islands again, Sweden would be endangered. He then asked Lord Curzon if Sweden should take the question to the peace negotiations, and if she did, would she be assured of British support? Lord Curzon replied that the dispute could be better amicably settled between Sweden and Finland, with the future safety of the Islands assured by proper guarantees. 12

Lord Curzon's reply was indicative of the distance the Allies wished to keep from the Aland question, at least during the negotiations in Paris. Lord Curzon gave no definite sign of British support other than to say that it seemed desirable for the Islands to be in the hands of a strong rather than a weak power. 13

The Alanders sent a delegation to Paris in January, 1919. They met with various delegates from the Allies, and expressed their desire to be reunited with Sweden. In their meeting with Henry White, an American delegate, they stressed their dependence on the "lofty principles" of Wilson's Fourteen Points, and also reiterated their case on the basis of language, culture, and strategic concern for Sweden. 14

12 Barros, The Aland Island Question, p. 134.

${ }^{13}$ Ibid.

14 Ibid., p. 130. 
Both Finland and Sweden had contacted allied representatives before the question was formally introduced at the Conference. From London, Lord Curzon observed that "the Finns had the best of the position, and the Swedes, on the whole, the best of the argument."15 At the same time, it was still his view that a settlement should be reached between Finland and Sweden.

Unable to come to agreement, either verbal or written, the Swedish government addressed a note to the Conference on April 22, 1919, asking that the Aland dispute be considered.

In the note, addressed to Clemenceau, as President of the Peace Conference, it was observed that the Alanders themselves had already brought the question to the attention of delegates to the Peace Conference. Bilateral discussions between Finland and Sweden had failed to bring a solution. The Swedish government felt bound to support the Alander's desire for self-determination. In addition, the Swedish government believed that the question was one which could be considered by the Conference when the problem of Finnish boundaries was settled. The Swedish government believed that the public opinion of both Finland and Sweden would accept the solution of the Paris Peace Conference; Sweden wished the dispute to be settled by plebiscite, and if granted to her by that means, Sweden wanted continuance of the Islands' former legal status, preventing military establishments there, or their being attacked by another power. 16

\footnotetext{
15 Barros, The Aland Islands Question, P. 143.

${ }^{16}$ Ibid., pp. 145, 146.
} 
Following the Swedish note, the Supreme Council of the Peace Conference recognized the independence of Finland and the Government in Helsingfors, France having already given recognition. The recognition was made without conditions, despite the British proposal that recognition be dependent on Finnish acceptance of the border settlement forthcoming from the Conference. That would have amounted to a carte blanche for the powers to decide the Aland question as well as the problem of Finland's Eastern frontiers, which arose directly from the war. 17

In June of 1919, a second plebiscite was held on the Aland Islands. Ninety-five per cent of those voting were in favor of union with Sweden.

At the Paris Peace Conference, the Aland question was considered by the Baltic Commission, of which Sir Esme Howard was the President. In his view, in the "absence of any agreement with the Russian government the Aland question would have to be 'entrusted to the League of Nations. " 18

If the Aland question were discussed and settled on the basis of national self-determination, by the Peace Conference, an unwanted precedent might be set -- that of the Peace Conference having the task of solving territorial transfers elsehwere. The British considered it preferable for the League of Nations to handle and rule on the dispute because of that.

17 Barros, pp. 147,148 .

18 Ibid., p. 159. 
In discussing the question, several alternative proposals were mentioned: (1) a condominium for the Islands could be established between Finland and Sweden; (2) a free state could be created under the protection of the League of Nations; (3) the Islands could be awarded to Sweden; or Sweden could give financial or territorial compensation to Finland in exchange for the Islands; (4) the Islands could be allowed to remain as part of Finland.

In any case, the Commission was in favor of reimposing the 1856 Convention on the Islands, and even of neutralizing them.

The Baltic Commission recommended on July 4, 1919, that the 1856 Convention should be maintained, and that the Islands should be neutralized under the authority of the League of Nations. The Commission was divided on the question of possession; Britain and the United States at that time favored a Finnish-Swedish protectorate over the autonomous Islands. The French, Italian, and Japanese delegates noted that because of the Islands' strategic importance, no settlement could be made without the consent of Russia, which was not then obtainable. ${ }^{19}$ No treaty as yet had been signed between Finland and Russia, and Russia was not represented at the Peace Conference.

The Commission's report did note that "if the question of any change of status in the Islands were to be decided by an international body, it had better be left to/a/decision by the League of Nations." 20 The problems of consideration by the Baltic Commission included some of the following: the allied powers recognized Finland, with the

19 Barros, The Aland Island Question, p. 167.

${ }^{20}$ Ib1d., qutoing Recomendation of the Commission on Baltic Affairs on the Aland Islands, Paris, July 4, 1919 (Political 1919: 11/468/468, League of Nations Archives). 
exception of Italy, but Russia was conspicuously absent from the peace talks. Contact with Russia was kept through Sazonov, then the Foreign Minister of the Kolchak government in Russia. And Sazonov is quoted as saying that "It would always be essential for Russia to keep a military force in Finland but also in the Gulf of Bothnia and there must be no question of ceding the Aland Islands to Sweden."21

Strictly speaking, the Aland dispute did not arise from the war and thus it did not "properly fall under the competence of the Peace Conference." 22 The Swedish delegate, Ehrensvard, maintained, however, that the whole question was a product of the war. 23

After hearing the Swedish delegate, the Baltic Commission made a second recommendation to the Supreme Council and suggested that a definitive settlement be made by the Peace Conference; the suggestion was dated August 25, 1919. No mention was made of the League of Nations.

Finally the Supreme Council of the Peace Conference ignored the second recommendation of the Baltic Commission; considering the determination of the Swedes and the Finns, and the difficulty of obtaining Russian assent to a settlement, the allied powers could only recommend that the 1856 Convention be imposed on whoever later possessed the Islands, and that they should be neutralized under a guarantee by the League of Nations.

$$
\begin{aligned}
& 21_{\text {Barros, p. } 155 .} \\
& { }^{22} \text { Ibid., p. } 168 . \\
& 23 \text { Ibid., p. } 179 .
\end{aligned}
$$


Essentially, the Peace Conference managed to delay the settlement and at the same time to allow for shifts of position to take place. The British, from prior sympathy for the Swedish position, had come to believe that their interests would be best served if Finland were not coerced into surrendering the Islands to Sweden.

France had initially agreed that the Islands be awarded to Sweden, but upon later reflection and a meeting between General Mannerheim and Clemenceau, France had changed her mind. France was interested in using Finland as a protector both against Germany and the Russian Republic. The idea of a cordon sanitaire beginning with a committed Finland rather than a neutral Sweden to the west, would be of value to the French.

By avoiding a settlement, undue antagonism of the Russian emigrés in Paris was also avoided; they were headed by Sazonov.

By not arriving at a solution among themselves for the Aland question, the great powers could recommend that one be found through the League of Nations; a settlement from the League could be seen as one where the great powers acted within the framework of that organization, yet the League would be a useful "façade" behind which Britain and France, especially, could exert influence and pressure for the so0 lution of the Aland question. Italy had been markedly non-committal; she was not willing to endorse the self-determination of the Alanders since that might put her claims in the southern Tyrol in jeopardy.

On May 6, 1920, the Finnish Diet passed an Autonomy Law giving cultural autonomy and partial political autonomy to the Aland Islands; the effect was not to calm the Alanders. They declared "qu'aucune 
mesure de ce genre ne pourrait diminuer leur désir d'être réunis à $1 a$ suède. Ils refusèrent d'accepter cette $10 i . " 24$

In May of 1920, another delegation from Aland was received in Stockholm by the King of Sweden; there the delegation again made known their anxiety caused by the lack of a settlement and their continuing desire for reunion with Sweden. The King counseled patience and confidence in Sweden.

Following that visit by Alanders, the Swedes expressed concern that the Alanders would present a fait accompli, by declaring union with Sweden, which would put Sweden in a difficult position.

The dispute had been submitted unilaterally to the Peace Conference, so it was still a matter that awaited its decision. Sweden, aware that no definitive solution would result from the Supreme Council, was in a difficult position to introduce the matter to the League of Nations. To request that the matter be dropped at the Paris Conference would be damaging to the self-esteem of Sweden, and would be tantamount to admission of defeat.

Initially, the Swedes had hoped that their case would be the stronger at the Conference, since Sweden had remained neutral in the war and was on the side of the principle of self-determination; Finland had cooperated with Germany, opening the possibility of suspicion by the allies. As time went on, the Swedes did not feel that the situation was ameliorated.

Tension grew as two leaders of the Alanders were arrested on June 5, 1920 by Finnish authorities on Aland; they were charged with high treason, and Finnish troops were sent to the Islands.

${ }^{24}$ Söderhjelm, p. 148. 
After an exchange of numerous notes, the Swedish Minister to Helsingfors was recalled to Sweden. It was obvious that Finland meant to keep the Islands, in spite of the wishes of the people there. The Finnish Minister in Stockholm was not recalled.

In view of the situation in the Baltic area, Lord Curzon, the British Foreign Secretary, submitted the Aland Islands Question to the Council of the League of Nations, basing his action on Article Eleven of the Covenant of the League of Nations.

Any war or threat of war, whether immediately affecting any of the Members of the League or not, is hereby declared a matter of concern to the whole League, and the League shall take any action that may be deemed wise and effectual to safeguard the peace of nations. In case any such emergency should arise the Secretary-General shall on the request of any Member of the League forthwith summon a meeting of the Council.

It is also declared to be the friendly right of each Member of the League to bring to the attention of the Assembly or of the Council any circumstance whatever affecting international relations which threatens to distur $b$ international peace or the good understanding between nations upon which peace depends. 25

${ }^{25}$ League of Nations, Covenant, Article Eleven, "Action in Case of War or Threat of War." 


\section{CHAPTER V}

\section{THE ÅLAND QUESTION BEFORE \\ THE LEAGUE OF NATIONS COUNCIL: 1920-1921}

In submitting the Rland question to the League of Nations Council, Lord Curzon addressed a letter to the Secretary-General, Sir Eric Drummond, dated June 19, 1920.

Dear Sir Eric Drummond:

I desire in exercise of the friendly right conferred by Article 11 of the Covenant of the League of Nations, to bring to the attention of the Counc1l of the League of Nations the case of the Aaland Islands, as a matter affecting international relations, which unfortunately threatens to disturb the good understanding between nations, upon which peace depends.

I do not take this step without having informed the two Governments, Sweden and Finland, of my intention to do so. 1

Following the submission of the question to the Council, Sir Eric Drummond gave notice that the Council would consider the question, and invited the Swedish and Finnish governments to present their cases. The League of Nations Council meetings from July 9 to July 12, 1920, in London, included representatives from Sweden and Finland; two envoys from Aland were 180 present.

The Finnish representative, Carl Encke11, insisted that the dispute was one between the Alanders and the government of Finland and that the dispute was not a threat to peace. According to Encke11, it was a

${ }^{1}$ Charles Noble Gregory. "The Neutralization of the Aaland Islands," The American Journal of International Law, XVII No. 1 (Januery, 1923), P. 63. 
question of internal policy where the League of Nations did not have competence. He based his argument on Article Fifteen, Paragraph Eight, of the Covenant of the League of Nations.

If the dispute between the parties is claimed by one of them, and is found by the Council, to arise out of a matter which by international law is solely within the domestic jurisdiction of that party, the Council shall so report, and shall make no recommendation. 2

The Swedish representative, Hjalmar Branting, insisted that the question was of an international character, suitable for consideration by the League Council.

Both countries accepted the 1856 Convention as operative in spite of the fact that the Russians had fortified the Islands during the war and in spite of the fact that in 1920 while the Council deliberations were in process, Finnish troops were stationed on the Islands. Sweden evidently did not consider the dispatch of Finnish troops to the Islands contrary to the 1856 Convention, though the presence of the troops was objectionable.

On July 12, 1920, the Council adopted a resolution establishing a Commission of Jurists to advise on the following two questions:

(1) Does the Swedish case as presented to the Council, on the question of the Aaland Islands, arise out of a matter which, by international law, is solely within the jurisdiction of Finland, within the meaning of paragraph 8 of Article 15 of the Convention?

(2) What is the present state of the international obligations regarding the demilitarization of the Aaland Islands? ${ }^{3}$

2League of Nations, Covenant, Article Fifteen, Paragraph Eight, "Disputes Not Submitted to Arbitration or Judicial Settlement." 64.

${ }^{3}$ Gregory, The American Journal of International Law, XVII, No. I, 
Branting and Enckell promised, on behalf of their respective governments, to maintain the peace while the Commission carried out its investigation.

The members of the Commission of Jurists were Professor F. Larnaude, Dean of the Faculty of Law of Paris, Professor A. Struycken, Councillor of State of the Netherlands, and Professor Max HUber, Legal Advisor of the Swiss Political Department. The Secretary, from the League Secretariat, was M. G. Kaeckenbeeck.

While the Commission of Jurists was at work hearing representatives of Sweden, Finland, and the Aland Islands, the Russian Ministry of Foreign Affairs broadcast a protest by radio to the League Council claiming, in part, that

il n'existe aucune stipulation ou tractat en vertu de laquelle la souveraineté de la république russe sur les Iles d'Aland aurait cessé d' exister. Aucune décision relative a ces 41 es ne sera donc valable parce que le gouvernement russe n'a pas été appele y participer.4

Russian absence at the Council deliberations in London was not a factor to be ignored; the protest by the Ministry of Foreign Affairs served to remind the Council members of Russian interest in the Baltic area which had also been noted at the Paris Peace Conference.

The Commission of Jurists reported to the Council on the two questions, on September 5, 1920. They advised that the Aland dispute was not purely a domestic matter; therefore it was one suitable for handling by the League of Nations.

${ }^{4} \mathrm{~J}$. 0. SBderhjelm, Démilitarisation et neutralisation des Iles d'Aland en 1856 et 1921 (Helsingfors, 1928), PP. 150, 151 . 
According to the Jurists, the question had arisen when Finland did not yet possess the character of a "'definitely constituted state". The position of the $\$$ land Islands had not been clearly defined due to military events in 1918, the movement for independence in Finland followed by separation from Russia, the objectives of the $\AA$ landers for union with Sweden, and the attitudes of Finland and Sweden.5

The Jurists denied Finland the right to force a political status on a national group which that group refused to accept; Finland, at the time of her declaration of independence and immediately following was not a sovereign state in their opinion.

The Jurists dismissed the recognition extended to Finland by several nations, following its declaration of independence, by noting that the recognitions had no value when given in wartime, especially when they were given by belligerent powers. In addition, the disorganization of political and social conditions made it difficult to establish exactly when Finland became a sovereign state. A1l of those factors were considered by the Jurists as "'intrinsic and special characteristics"" which gave the dispute an international character. ${ }^{6}$ Thus, for what may be considered somewhat novel reasons, the question was declared an international one.

The Swedish point of view was clearly supported by the Jurists' report on the first question.

5ames Barros, The Aland Islands Question: Its Settlement by the League of Nations (New Haven: Yale University Press, 1968), p. 290.

6arros, The Aland Islands Question, P. 291. 
As to the second question, the Commission of Jurists advised that the 1856 Convention of the Treaty of Paris was still in force. It was pointed out that the provisions of the treaty were established in "'European interests" and created a special "'international status" for the islands. The Jurists advised that until the 1856 provisions were replaced, "every interested state could insist on compliance and the state in possession must conform to the obligations they imposed."7 Due to the European interests served, Finland was bound by the obligations of the 1856 Treaty. In the Jurists' view, it also meant that Sweden could insist on compliance with the provisions of the treaty as an "interested state", though not a signatory to the Treaty. The Swedes could only be content with the Jurists' advice.

Regarding the question as to the effect of the war on the Convention of 1856 , the Jurists noted that the Russian fortifications had not affected the Convention and that the three signatories, Britain, France, and Russia were allies during the war; the agreement could not be considered abolished by the war. 8

After the report by the Commission of Jurists, the Council of the League of Nations was not in a position to refuse to consider the matter.

The Jurists' view of Finland succeeding to the treaty obligations which she had no part in creating provides an exception to the principle of succession with regard to treaties. Usually treaties are valid only

\section{${ }^{7}$ Gregory, The American Journal of International Law, XVII, No. 1 , 64.}

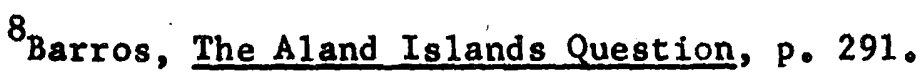


so long as a state exists; succession does not take place with regard to duties and rights stipulated by treaties, the reason being that treaties are "personal" obligations attached to a state for as long as the state exists; they are not considered territorial phenomena.

The $\&$ land Islands case is an exception to that principle. The Jurists declared that the stipulations of the 1856 Convention or Servitude constituted part of the public law in Europe; the Convention had an international character rather than a personal character. Thus the Treaty obligations are assumed to survive the succession of states in that case.

sbderhfelm, writing in 1928, regarded the question of succession in the case of Finland from the opposite point of view.

Il faut donc constater que la règle générale selon laquelle un état successeur n'assume pas les engagements personnels, obligations au point de vue du droit des gens, du predecesseur, est applicable aux dispositions de 1856 dans le succession Russie-Finlande, et que ces engagements, au moment même où la Finlande devenait Indépendente, cessait d'exister. Lorsque commenfait la phase critique de la $\gg$ question des lies d'Aland》, la Finlande ${ }^{n}$ 'Etait tenue par aucune engagement relatif aux Iles. 9

Left with the dispute to consider, the League of Nations Council meeting in Paris on September 20, 1920, adopted a resolution which provided for a Commission of Inquiry to be appointed to report "sur le règlement definitif ou provisolre de la question des Iles d'Aland, en tenant compte des interets de toutes les parties et de nature a fablir des conditions favorables au maintien de la paix."10

\footnotetext{
${ }^{9}$ sbderhjelm, DSmilitarisation et neutralisation des 1 les d'Aland, p. 143.

10 syderhjelm, Démilitarisation et neutralisation des Tles d'Aland, P. 151 .
} 
The members finally chosen to participate on the Commission of Inquiry were Baron Eugene Beyens, former Foreign Minister of Belgium, Felix Calonder, former President of the Swiss Republic, and Mr. Abram I. Elkus, former American Ambassador to Constantinople.

During the Autumn and Winter of 1920-1921, the Commission of Inquiry went to Sweden, Finland, and to the $\$$ land Islands. It is perhaps not without significance that they traveled between Finland and Sweden during the winter months when the geographical relation of the $\AA$ land Islands to the Finnish mainland is most conspicuous.

While the Commission was compiling its report, the Swedish and Finnish governments were drawing up preliminary proposals for the settlement of the dispute under the auspices of the League; the proposals provided the bases for the new Convention agreed upon later in Geneva.

The Commission's inquiry resulted in a long report which contained a geographical and historical summary as well as a consideration of the legal-political aspects of the dispute.

The Commission observed that the $\AA$ land Archipelago was a continuation of the Finnish mainland. Not only would a new border, to the East of the $\mathrm{A}$ land Islands between the mainland and the Islands, be difficult to draw, but Finland would be in a weaker defensive position especially due to the freezing of the "Skiftet" during winter months.

According to the Commission of Inquiry the important question about the dispute was whether or not Finland was the rightful sovereign over the \&land Islands. The Commission was of the opinion that Finland's condition as a sovereign nation could be dated from the time of its declaration of independence from Russia in 1917, and that in spite of the civil war which followed, the Finnish Government had not lost its 
soverelgnty. On the question of dating the sovereignty of Finland the Commission of Inquiry obviously did not concur with the report of the Commission of Jurists.

The Commission of Inquiry noted that in 1917 the $\$$ land Islands constituted part of independent Finland and that as such, the western frontiers of Finland were clearly defined. In effect, the Commission was informing Sweden that she had no grounds to argue that her recognition of Finland did not imply recognition of her borders. The Swedish argument was especially weak in that her recognition of Finland was without reservations in January, 1918. Moreover, the Commission noted that Sweden had "'renounced the possession of the Archipelago forever" by the Treaty of Frederikshamn. According to the Commission, Finnish sovereignty over the $\AA$ land Islands was "incontestable'"; they were legally part of Finland. 11

The Commission of Inquiry believed that Finland was willing to give guarantees to protect the nationality of the $\&$ landers; that being the case, they did not approve awarding the Islands to Sweden. Historical, geographical, and political arguments favored the status quo, Consideration was also taken of Finland's service to herself and others in stemming the Russian advances along the northern Baltic. To take territory which was considered so important by the new state could only be seen as ingratitude and increased the possibility of Finnish alienation from her Scandinavian neighbors.

11 Barros, The Aland Islands Question, P. 315. 
The suggestion that the Islands be given their independence was rejected by the Cormission on the grounds that they would not constitute a viable state, even if Finland would agree to their independence. The recommendations of the Commission of Inquiry dealt with two areas: the Aland Islands under the sovereignty of Finland but subject to extensive guarantees for the nationality of the population, and the question of the demilitarization of the Islands.

On the latter topic, the Commission proposed that the military status of the Aland Islands should be regulated by a special convention for neutralization. ${ }^{12}$ The report of the Jurists had accepted the Convention of 1856 as still in force, but the Commission of Inquiry suggested stronger guarantees and stricter clauses be implemented to prevent the recurrance of actions like Russia's during the war. 13

The proposals to guarantee the \&landers' minority status in Finland included the following: all instruction in the public schools was to be given in Swedish, instruction in Finnish in the public schools being excluded by law; \&landers were to have priority on land purchase when offers to buy land were made by outsiders; settlers newly arrived would be granted the franchise after five years residence; the Governor of the Islands was to be chosen by the Helsingfors Government from a list of three candidates proposed by the Alanders. 14

${ }^{12}$ sbderhjelm, Demilitarisation et neutralisation des Iles d'Aland, P. 150 .

13 Barros, The Aland Islands Question, P. 318.

${ }^{14}$ Ibid. 
The Commission did not approve of using a plebiscite to settle the matter but suggested that if the guarantees were not granted by the Finnish government, the wishes of the Alanders could be determined by a plebiscite.

Assuming that the Council would adopt the Commission's recommendation and that the Finnish Government would adopt the proposals for guarantees, the Commission belleved that the status of the Islands could be agreed upon in a manner that was acceptable to the Alander population. On the question of possible further disputes or difficulties, the Commission left the right of intervention to the Council of the League. Also, the Alanders were to have recourse to the "good offices" of the Counc11; recourse did not mean that the $\$$ landers could directly approach the Council, rather that one of the Scandinavian countries might approach the Council on behalf of the $\AA$ landers if differences arose regarding the application of accepted guarantees.

After the report was compiled in the Spring of 1921, the League Council, meeting in Geneva, considered the recommendations of the Commission of Inquiry.

Recognition of Finland's sovereignty was an obvious blow to the Swedish case; and it was clear from the negotiations following that national self-determination was not a principle that the commissioners would recommend to be carried to extremes. Considering that one Belgian and one Swiss were members of the Commission, it is not surprising that the right of free self-determination, applied to a minor part of a nation, was rejected; at the same time it was established that the minority was definitely not suffering wrongs and injustice. 


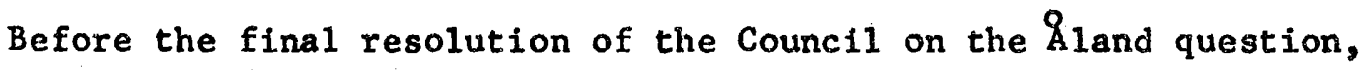
representatives from both Sweden and Finland agreed to accept the decision of the Council. Branting hedged, however, noting that "future events may take place independently of the will of the Swedish government, creating a new situation in the islands, which it may be impossible to consider as covered by the decision of the Council.'"15

The Council adopted a resolution on June 24,1921 , recognizing Finnish sovereignty over the Islands coupled with the need for guarantees for the Alanders. The guarantees of language, property, franchise, and selection were to become part of the Autonomy Law in Finland. Those guarantees were to be decided in bilateral talks between Sweden and Finland, with Council assistance if necessary.

So that the Islands could never become a military threat to Sweden or to any other power, the 1856 Convention was to be replaced by a more comprehensive treaty of neutralization; to that end a conference was to be called by the Secretary General of the League.

Compromises on the guarantees for the $\AA$ landers were arranged between the Swedes and the Finns; the Swedes realized that their case was losing. Major differences in opinion arose over the selection of the Islands' Governor and the question of access to the League of Nations Counc11.

It was finally agreed on the question of access to the Council that Finland would forward $\AA$ lander complaints, along with its own observations to the Council.

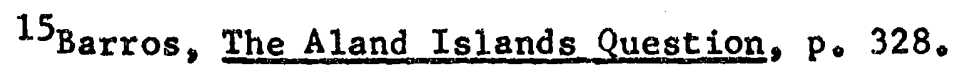


The Governor was to be nominated by the President of Finland in agreement with the President of the Rland Landsting. If an agreement. could not be reached, the Finnish President was to choose the Governor from five candidates nominated by the Aland Diet, Landsting. 16

The guarantees of property, franchise, and language were accepted substantially as they had been recommended by the Commission of Inquiry.

The application of the guarantees was to be watched by the League of Nations. No provision was made for official observation, to this writer's knowledge. If a case of a fudicial nature arose, the Council was to consult the Hague Court.

The compromise guarantees were adopted on June 27, 1921, and annexed to the resolution approved by the Counc11 on June $24,1921$.

The British representative to the League Council from 1920 , Herbert

A. L. Fisher, wrote the following diary entry on June 27, 1921:

We have reached a settlement, not without difficulty, for both the Swedes and the Finns were very obstructive, of the Aland Islands question and the settlement is so intrinsically just and fair and is 80 obviously framed in the interests of Euro: pean peace that I have 1 ittle doubt but that it will stand. 17

In letter of the same date he admitted:

We succeeded . . In extracting from the Finns a considerable enlargement of the law of autonomy, which delights the Alanders and it is significant that the Finnish Gov't. would never have made these concessions to the Swedes, though they were prepared, after a little steady pressure, to make them to the Council of the League. Indeed, it is clear to me now that

16 Barros, The Aland Islands Question, p. 333.

17 Barros, The Aland Islands Question, p. 333 quoting Fisher Papers, Diary entry, June 27, 1921. 
the dispute could never have been settled by the ordinary methods of diplomecy. 18

There remained the question of a new agreement to establish the neutralization of the Islands. On July 12, 1921, the Secretary-General of the league of Nations invited interested states to a conference in Geneva to consider the neutralization question, one that had been suggested at the Peace Conference in Paris, 1918, and was recommended by the Commission of Inquiry as well as by the League Council in 1921.

${ }^{18}$ Ibid. quoting Fisher Papers, Fisher to Murray, June 27, 1921. 
CHAPTER VI

THE CONFERENCE IN GENEVA: 1921

The invitation to the Conference in Geneva by the Secretary-

General of the League of Nations went to ten nations: Germany, Denmark, Estonia, Finland, France, Great Britain, Italy, Latvia, Poland; and Sweden.

Russia protested her lack of invitation, noting in part in a letter to the Finnish President and Minister of Foreign Affairs:

Le Gouvernement Russe a appris que le Gouvernement Suédois faisait des demarches pour la convocation d'une conference des puissances intéressées concernant la neutralisation des iles d'Aland. Le Gouvernement Russe s'Etonne qu'aucune invitation ni même notification à ce sujet ne lui ait té faite. La Russie, comme puissance riveraine de la Mer Baltique est hautement intéressée à toute solution sur les lles d'Aland, dont la position geographique donne toute decision les concernant une importance particulière pour les masses travailleuses de la Russie. ... Tant que ces lles forment une province de la Finlande, le Gouvernement Russe n'intervient pas. Si cette attribution cesse ou si leur status international change en quelque chose, la Russie est obligee dans ce cas, de réclamer sa participation aux décisions qui seraient prises à cet Egard. 1

The Council resolution of June 24,1921 , to call a conference in order to replace the 1856 Convention on the Aland Is lands may be seen as a gross extension of Council powers. Article Five of the resolution provided that

un accord international en vue de la non-fortification et de la neutralisation de 1 'Archipel doit garantir au peuple suedois et

1J.0. Soderhje1m, Demilitarisation et neutralisation des Iles d'Aland en 1856 et 1921 (Helsingfors, 1928), p. 170. 
à tous les pays intéressés que les 1 les d'Aland ne deviendront jamais une cause de danger au point de vue militaire. $\hat{A}$ cet effet, la Convention de 1856 doit être remplacée par un accord plus large, placé sous la garantie de toutes les Puissances Intéressées, y compris la Suède. Le Conseil estime que cet accord devrait se conformer dans ses grandes lignes au projet suédois de convention pour la neutralization des îles. Il charge le Secrétaire-Général d'inviter les Gouvernements intéressés à désigner des représentants dûnent accredités pour discuter et conclure le traité proposé. 2

The Conference convened in Geneva on October 10, 1921. According to Söderhjelm, the Representatives of the states not directly interested in the Islands arrived in Geneva with the preconcelved notion that Sweden should in some way be compensated for her acceptance of the League resolution. Also, it was assumed that the demilitarization of 1856 was still adequate, and that negotiations would most likely concern neutralization and a guarantee. ${ }^{3}$

During the first session the Danish Representative, Bernhoft, was elected President of the Conference. A Commission of three composed of Representatives from Great Britain, France, and Italy, was charged with effecting agreement between the Representatives of Finland and Sweden.

Once the issue of Finnish sovereignty was clear to all Representatives, the negotiations moved quickly. There were a total of five proposals submitted for consideration, beginning with the "premier avant projet suédois," followed by the "premier avant projet finlandais," which in turn was followed by the "deuxième avant projet suédois." In al1, three Swedish proposals, and two Finnish proposals were considered before the final Convention was drawn up.

$$
\begin{aligned}
& { }^{2} \text { söderhjelm, p. } 168 . \\
& { }^{3} \text { Ibid., p. } 173 .
\end{aligned}
$$


The first proposals reflected attitudes of January, 1921, before the Council had definitely declared the Islands to be under Finnish sovereignty. The Swedish proposals were the broadest when it was assumed that there was still a chance of the Islands becoming Swedish. But as Finnish possession was undeniable, the last Swedish proposal was more restrictive.

The Convention of 1921 is properly called the "Convention relative à la non-fortification et à la neutralisation des $̂$ les d'Aland." The Convention provides for demilitarization, neutralization, and a guarantee of the Islands' status. Once neutralization had been provided for, the articles calling for demilitarization and guarantee were mainly accessory. The neutralization of the Islands established that they would be kept out of military operations and that military utilization of them would be impossible; demilitarization reinforced the neutralization, stipulating that no military establishment or base of operations could be created or maintained in the Aland Islands zone described in the Convention.

The 1856 Convention, by contrast, provided only for the demilitarization of the Islands; they were not then neutralized.

La clause d'Aland de 1856 est par son caractère une démilitarisation. Il ne s'agit pas de neutralisation: on n'y établit pas une interdiction génerale d'entreprendre des opérations militaires dans 1 'archipel, d'y tenir des troupes ou du mat'eriel de guerre ou de prendres d'autres mesures, de quelle nature qu'elles soient, en vu de la défense ou de l'offensive. Les dispositions se bornent à deux interdictions positives: celle de fortifier les Ales d'Aland, et celle d'y maintenir des établissements militaires ou navals. 4

${ }^{4}$ söderhjelm, p. 109. 
The Convention of 1856 did not foresee the use of air power or subrnarines; the 1921 Convention provides for the territorial waters as well as air space above the zone to be neutralized.

No provision was made in the 1856 Convention for the signatory powers to intervene if Russia did not observe her treaty obligations. The 1856 Convention was clearly conceived as a two sided agreement with France and Great Britain on one side seeking to check Russia on the other. The states in the 1921 Convention concluded the agreement as equals; Finnish possession of the neutralized zone was not seen as a settlement imposed on her by the other powers.

The official paragraphs beginning the Convention state that the contracting parties conclude an accord, after the resolution of the League Council, to neutralize and demilitarize the Aland Islands, and to guarantee that the Islands would never become a military threat; to that end they resolve to perfect, without infringing upon, the engagement made by Russia in the Convention of March 30, 1856.

By Article One, Finland confirms the Russian adherence to the 1856 Treaty, and commits herself not to fortify the Aland Islands. Article Two defines the zone of the Aland Islands by geographical reference to longitude and latitude, and establishes that the territorial waters of the Islands extend for three nautical miles.

Military operations and establishments for army, navy, or air force are prohibited in the zone, by Article Three.

By Article Four, the army, navy, or air force of any power is forbidden to enter or remain in the zone; manufacture, importation, transit, or re-exportation of arms and war material is expressly forbidden. 
Aside from regular police force in the zone, Finland may send troops to be stationed there temporarily to maintain order in exceptional circumstances. And Finland is given the right to visit the zone occasionally with one or two light suface naval vessels. They are allowed temporary anchorage in the neutralized zone. If circumstances required it, Finland may send other vessels temporarily to the zone, the total displacement of those vessels not exceeding 6,000 tons.

For a naval vessel of another state to enter the zone, permission must be granted by the Finnish government, and only one vessel at a time is allowed anchorage in the archipelago.

Finland may provide aerial surveillance over the zone, but landing is prohibited except in the case of absolute necessity, "force majeur."

According to Article Five, the prohibition of naval vesse1s, "navires de guerre," in the zone does not infringe upon the rights of inoffensive passage across territorial waters established by international rules and practices in force.

Article six describes the zone as neutral and prohibits it from becoming directly or indirectly used in any way for military operations. If a war occurs in the Baltic, Finland may place teroporary mines in the water and establish strict maritime regulations there. In time of war, Finland is to notify the Council of the League of Nations immediately.

By Article Seven, the contracting parties address the Council of the League so that it can decide the measures to take for assuring the observance of the Articles of the Convention, in an attempt to curb violation of the Convention. 
The contracting parties agree, "s'engagent," to contribute to" the measures recommended by the Council.

The Council is given power to call the contracting parties to session, regardless of their membership or non-membership in the League of Nations. In deliberations in case of violation of the Convention, the vote of the Representative of the power accused of violation will not count toward the unanimity required for a decision by the Council. If unanimity is not achieved the parties are authorized to take measures recommended by a majority of two-thirds, the vote of the representative of the accused power not counting.

If the neutrality of the zone is placed in sudden peril, Finland is authorized to take the necessary measures to contain and repel aggression until the contracting parties may intervene to protect the neutrality of the zone. Finland should refer the case to the Council of the League of Nations immediately.

According to Article Eight, the Convention is to remain in force no matter what modifications of the status quo take place in the Baltic.

By Article Nine, the Council of the League of Nations is asked to bring the Convention to the attention of members of the League so that the status of the Islands, "partie integrante de la République de Finlande," might be respected by all in the interests of general peace. With the unanimous consent of the contracting parties non-signatory powers may formally adhere to the Convention.

Article Ten, the final Article, provides that the Convention would be ratified as soon as the majority of signatories (including Sweden and Finland) had deposited their ratifications in Geneva. The Convention entered in force for each power upon the deposit 
of her ratification or act of adhesion. 5

The Delegates signed the Convention on October 22, 1921; it was declared in force on April 6, 1922.

There are no provisions for modification or abrogation of the Convention; it is to remain in force forever, "बे toujours."

Article Eight leaves the impression that the situation in the Baltic was not stable, that changes in the possession of the coastal areas were not impossible, and that the position of Russia was not completely clear.

When Article Eight and Nine are read together, the impression is not that the Convention would remain in force if Finland lost possession of the Aland Islands. Söderhjelm wrote:

Il n'existe pas de règles du droit international créant à Aland une servitude ou un autre institut juridique qui per-
sisterait en cas de passage de ce territoire 8 un autre Etat.

The Articles of the Convention are to remain in force, but Article Nine stipulates that the Aland Islands are "partie intégrante de 1a Republique de Finlande;" it is assumed that once they were no longer part of the Republic of Finland the Articles would no longer apply. The Convention speaks only of Finland in possession of the Islands, instead of the state who possesses the Islands.

La Convention suppose évidemment que les $̂$ les se trouvent sous la souveraineté de la Finlande; si cette condition venait à cesser, la Convention ne serait plus obligatoire pour les puissances signataires. 7

5"Convention relative à la non-fortification et à la neutralisation des îles d'Aland," söderhjelm, pp. 372-378, Appendix.

${ }^{6}$ Söderhjelm, Démilitarisation et neutralisation des Ales d'Aland, p. 321 .

7 Ibld., p. 322 . 
In addition, it is assumed that if the Convention cannot protect the Islands against agression, Finland is entitled to defend that part of her territory. Söderhjelm wrote of Finland:

E1le a consenti à une restriction de sa souveraineté sur le territoire neutralisé sous la condition que la garantie concomitante fonctionne et se montre effective; sinon elle est déliée des clauses de la Convention. ... La Finland reprend alors intégralement son droit naturel de défendre son territoire.8

In terms of the guarantee, the League Council is placed in a position probably not envisaged by the Covenant writers. Nevertheless, it is the guarantees of neutralization and demilitarization by the Council's authority which give force to the provisions of the treaty. "De leur solidité dépend 1 'existence de ce bel édifice juridique." 9

The League of Nations provided a permanent body to consult or call upon, complete with available staff, and it appeared at the outset that the force of the provisions of 1921 Convention would increase in proportion to the force and importance granted the League of Nations.

Once the Convention was established, the general assumption was that the conditions specified were acceptable in terms of peace and safety.

Finland was in reality put in a somewhat weak defensive position; though she was probably powerless to use the Islands as a base of attack, they remained an open flank for aggression against her simply because the fortifications no longer existed. In effect, the fortifications could have been retained even while the Islands acquired a neutralized status, and Finland would have gained some protection on

${ }^{8}$ Söderhjelm, p. 296.

9 Ib1d., p. 330 . 
her western flank.

The other argument is of course, that once an aggressive power took the Islands the fortifications would only aid in an offensive against the Finnish mainland and Sweden. Once installed in the Islands, it would be hard to drive an enemy out; assuming that the Articles remained in effect in case of invasion, how could Finland rid the archipelago of an enemy force with her total tonnage not exceeding 6,000 tons?

The Pirst Article of the Convention left some questions too. Finland, in assuming the obligations not to fortify the Islands, accepts Russian adherence to the 1856 Treaty. The question then arises: once Finland has assumed those obligations, is the 1856 Convention automatically replaced by the remainder of the Articles of the 1921 Convention? The succeeding Articles do not make that clear. One factor is noticable however; the contracting parties in the introductory paragraphs do not clearly dispose of the 1856 Convention; their stated end is to perfect, "completer, sans y porter atteinte, de l'engagement pris par 1a Russie," the result of the agreement made by Russia in 1856. Though Russia protested the final Convention, she cannot have been too disturbed by the neutralization. In the Treaty of Dorpat between Finland and the Russian Socialist Federative Soviet Republic, signed on October 14, 1920, Article Twelve stated:

The Contracting Parties shall in principle favor the neutralization of the Gulf of Finland and the entire Baltic Sea, and undertake to cooperate for its neutralization. 10

10Anatole G. Mazour, Finl and Between East and West (Princeton: D. Van Nostrand Company, Inc., 1956), p. 214, "Treaty of Peace Between the Republic of Finland and the Russian Socialist Federative Soviet Rew public," 1920. 
Sweden was understandably content that the Islands were neutra1ized; neutralization had been suggested by Swedish negotiators dating from the 1856 Peace of Paris. That the Swedes had lost their case as 0 advocates of Alander self-determination before the League Council was undeniable.

The press in Sweden had generally supported the governments which pressed for reunion of Aland with Sweden. The two main reasons were strategy and the principle of self-determination, with greater emphasis placed on the self-determination argument.

Some cautious voices, however, had reminded the Swedish public that the Aland Islands had never been a "Swedish Irredenta", and that to possess them could be as much a military liability as an asset. 11 The League Commission of Inquiry had noted in 1920 that "Swedish public opinion was not deeply involved and that there was no danger in any circumstances of a breach of peace by Sweden." 12

Sir Esme Howard had been correct in his observation in 1919 that "for Finland the loss of the Aland Islands would cause far greater irri-* tation than the disappointment that would arise in Sweden if Sweden's interest in this matter were not satisfied."13

In the eyes of the international community Sweden appeared as a nation who was willing to accept the consequences of a decision made

11 Herbert Tingsten, The Debate on the Foreign Policy of Sweden: 1918-1939, trans. Joan Bulman (London: Oxford University Press), p. 92 .

12 Ibid., p. 135.

${ }^{13}$ James Barros, The Aland Islands Question: Its Settlement by the League of Nations (New Haven: Yale University Press, 1968), p. 171. 
by the League Council in one of the few successful settlements attributed to that body. ${ }^{14}$ The fact that power considerations decided the fate of the Alanders cannot be overlooked; the credit that the League received sometimes obscures the role of Britain, the positions of France and Germany, and the uncertainty over Russia in the years immediately following the First World War.

${ }^{14} \mathrm{~s}$. Shepard Jones, The Scandinavian States and the League of Nations (Princeton: Princeton University Press), p. 253. 
Once Finnish sovereignty over the $\mathbb{1}$ land Islands was established by the League of Nations resolution, the focus was on the autonomy to be allowed the Alanders.

The Autonomy Law, passed by the Finnish Parliament (Diet) in 1920, was still in force in spite of the fact that the $\& 1$ anders declared their refusal of it prior to the League Council resolution on June 24,1921 . Further legislation was passed insuring that \&1and would be an autonomous province with its Swedish nationality guaranteed. The guarantees and provisions recommended by the League Council were put into effect by the Finnish Government by legislation on December 9,1921 , and by a special guarantee law which was enacted in $1922 .^{1}$ The de facto Landsting of Aland finally accepted the Autonomy Legislation, and new elections were held in May of 1922. On June 9, 1922, the Provincial Assembly, Landsting, elected by direct election, met in its first session. Reprisals from the Finns toward the Alanders were not forthcoming, though the fear of being "fennicized" remained. From 1922 to 1938 the \&land Islands question was quiescent. The Alanders were preoccupied with exercizing the legislative and adminis-

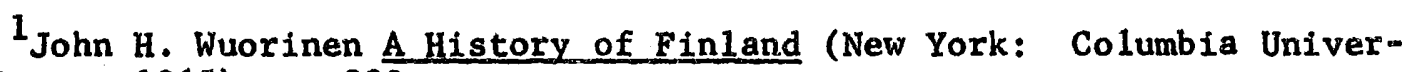
sity Press, 1965), p. 299. 
trative authority granted them within the framework of the Republic by the Autonomy Legislation. In the absence of mafor international crises in the Baltic area, the neutralized status of the Islands seemed acceptable and workable. Events imnediately preceding World War II prompted reconsideration of the Islands' non-fortified status, however.

In 1934, Marshal Mannerheim, Chairman of the Finnish Defense

Council wrote:

The solution of the $\$$ land Question has.. been mentioned as a good example of the way in which serious differences of opinion can be adjusted without jegpardizing security. But is this really the case? Has the Aland convention, which smoothed out the most serious differences that had separated the two Scandinavian Countries for so long, not done so at the price of possible future dangers, by opening a road to the north between the two countries? Anyone who tries to form even a superficial opinion of the defence problems of the North must realize that the very reverse of increased security has been the result of the convention.2

On August 11, 1938, Finland presented the Soviet Union with a draft for a treaty which stipulated that Finland's neutrality would not permit the use of her territory by another great power to attack the Soviet Union; the Soviet Union was to respect the territorial integrity of Finland and agree that Finland could take military measures on $\AA 1$ and in peace time in order to protect Finnish territorial integrity and to assure the "continuance of the greatest possible neutrality of $\AA$ land." 3

The draft for the treaty was in effect a feeler to determine Soviet reaction to joint Finnish-Swedish defense plans for the Islands.

2Karl Gustav E. Mannerheim, The Memoirs of Marshal Manneheim, trans. Count Eric Lewenhaupt (New York: E. P. Dutton and Company, 1954), P. 282 .

3 Mannerheim, Memoirs, p. 294。 
The Soviets replied that a treaty where Finland agreed to repel any German attack and to accept Soviet armed assistance would be acceptable. In addition, the Soviets agreed to the fortifications of the Aland Islands only if they were allowed to "participate, to supervise the work, and to control the use of the fortifications. 14 In return the Soviets asked for a fortified air base and a naval base on Hogland Island. The Finnish reply to the Soviet conditions was that acceptance would amount to a breach of her sovereignty and it would be a policy opposed to Finnish neutrality.

Swedish-Finnish contact was maintained concerning the defense of the Islands; Marshal Mannerheim noted that "the Swedes were as worried as we were about the defenceless position of \&land." 5

Defense plans were drawn up in 1939 and put before the Parliament of Finland and the Riksdag in Sweden. The plans, collectively known as the Stockholm Plan, consisted of measures to be taken in the archipelago. Coastal artillery positions were to be established in the southern skerries of the archipelago, military service was to be required for the \&land population, and anti-aircraft defense for the main1and was to be created. Swedish troops were to join in the defense to ease the $\AA$ lander fears of becoming "fennicized." See boundary revisions planned in Figure 3.

The Stockholm Plan was based on the assumption that Swedish and Finnish neutrality in a forthcoming conflict would be easier to maintain

4

Ibid.

${ }^{5}$ Ibid., p. 295. 
if the vacuum created by the $\AA$ land Convention were eliminated: A fortified archipelago would be lesser temptation to the great powers in the Baltic than one unfortified. In addition, the Gulf of Bothnia would be protected and the forces deployed there could be used elsewhere for other tasks.

The Stockholm Plan called for a revision of the 1921 Convention. Finland and Sweden sought the approval of the other signatory powers. Those powers accepted the plan for revision with no objections; Germany especially looked with favor on the defense plans since it would have meant increased protection for iron ore shipments from the Gulf of Bothnia. Great Britain did not object, but her reply stipulated that the Soviet government should be consulted and that the question be submitted to the League of Nations Council.

At Sweden's request, confirmation of the Plan by the Soviet government was sought; the Soviet Union, though not a signatory to the 1921 Convention, refused to agree to a revision of the Convention. In discussions at the League of Nations in May of 1939, the Soviet government made it clear that it wished the status quo of the \&1and Islands to be maintained. Objection to revision was made on the grounds that re-militarization would threaten Soviet security.

The Soviet position proved to be an influence on Swedish policy; the Swedish government withdrew the proposition from the Riksdag in June, 1939. No further steps were taken to jointly fortify the Islands. The Plan was approved by the Finnish Diet, but with Swedish support not materializing, the Finns were left to face the threat of a war with a defenseless archipelago. At the outbreak of the war, Finnish troops were garrisoned on Aland, and coastal forts were built 
on four outlying Islands in the archipelago.

According to the Autonomy Legislation that applied to the $\AA_{1}$ and Islands, the $\AA$ landers were not subject to conscription, in keeping with the neutral, demilitarized status of the Islands. The Autonomy Legislation could only be legally altered with the consent of the $\AA$ land Landsting.

The plan to conscript $\AA$ landers as well as to alter the $1921 \AA$ Aland Convention brought strong reaction from the Aland population.

In Apri1, 1939, the Alanders sent a letter to the Council of the League of Nations stating their opposition to the Stockholm Plan.

Aland considers that the proposed alteration would constitute a serious danger to the solemnly pledged neutrality of the Aland Islands and the application of the nationality guarantees embodied in the law. In view of the possible consequences which an alteration in the status quo might have, and of their respogsibilities toward future generations, the people of the Aland Islands feel it their duty to make a serious protest against the measures now planned, which directly threaten their well-being.

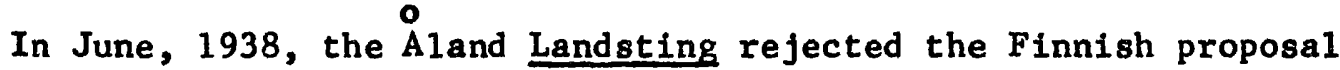
that the conscription measure be approved by the Landsting. The language of command of the forces was to be Swedish, and service personnel stationed on the $\AA$ land Islands were to be Swedish-speaking. The vote was twenty-one to seven. The Alanders were committed to the status quo of the Islands even in the face of a future war.

From the \&landers' point of view, any change in the 1921 Convention was clearly a threat to the autonomous existence of the Islands; 7

6 Herbert Tingsten, The Debate on the Foreign Policy of Sweden: 1918-1939, trans. Joan Bulman (London: Oxford University Press, 1949), p. 251.

7Matts Dreijer, "Då âlunningarga KHmpade fHr sina konstitutione11a rHttigheter," SHrtryck ur tidningen Aland: nr.9-1965, p。10, 11 . 
that Convention in force along with the League Council Resolution of June 24, 1921, the "Magna Charta" for \&land, were held sacred by the law-oriented Alanders. They were aware of their relatively insignificant size and influence and so perhaps their trust in existing legal arrangements was augmented.

The 1938-1939 Aland question bears comparison with the 1918-1921 dispute. In 1918-1921, the $\AA 1$ anders asked concessions in the form of reunion with Sweden; the official Swedish position was that the Islands should be reunited with Sweden, and that they should not be fortified or used for any military purpose. The Finnish view was that neutralization was acceptable, but that sovereignty over the Islands was definitely hers. Sweden and Finland were then parties to a kind of international "lawsuit".

By 1938-1939, the Swedish and Finnish governments were fointly planning for the defense of a once-disputed territory. Finland was, in effect, asking concessions from the Alanders to introduce conscription on the Islands. Both Sweden and Finland agreed that remilitarisation was necessary, and the Stockholm Plan provided for Swedish support in the Islands. The question of sovereignty over the Islands was not revived in 1939 .

By the Swedish view,

'In 1920 an unfortified Swedish Aaland, in 1939 a fortified Finnish Aaland was to form a bridge between Sweden and Finland; in 1920 a fortified Aaland was a pistol aimed at Sweden, in 1939 an unfortified Aaland was an aerial bomb aimed at the heart of Sweden.' 8

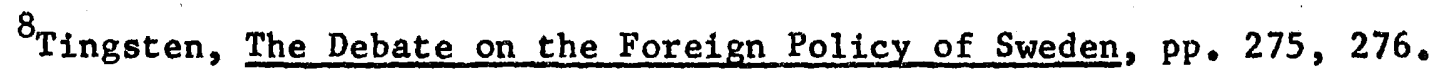


The Swedish withdrawal of the Stockholm Plan from the Riksdag illustrates the extent to which the status of \&land Islands is determined by interested states greater than Sweden and Finland. Technically, the two countries could have proceeded with the Stockholm Plan after having consulted the signatory powers; practically, incurring the displeasure of Russia and the dissatisfaction of the $\AA$ landers proved to be an obstacle to implementing the Plan。

In 1940 Finland had a choice between demilitarization of the Islands or fortification in cooperation with the Soviet Union; she chose the former. 9

Following the Winter War, the U.S.S.R. and Finland signed an

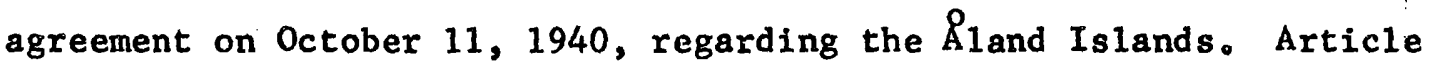
One of that agreement provided that

No establishment or base of operation, military or naval, no establishment or base of operation of military aviation, no other establishment capable of being used for military purpgses, can be maintained or constructed in the zone of the $A$ land Islands either by Finland or by other states, and existing artillery platforms must be razed. 10

Also by that agreement, the U.S.S.R. was to appoint a consul to the Islands; he was to "supervise fulfillment of Finland's pledges regarding demilitarization and non-fortification of the Islands"11 in addition to regular consular duties.

The Alanders felt very keenly dependent on the Autonomy Leglslation and the 1921 Convention. Their position was a somewhat precarious one

${ }^{9}$ Anatole G。 Mazour, Finland Between East and West (Princeton: D。 Van Nostrand Company, Inc., 1956), p. 135 .

10 Vera Micheles Dean, Europe in Retreat (New York: Alfred A. Knopf, 1941), p. 413 .

${ }^{11}$ Ibid. 
during the Second World War. Some Soviet bombs were dropped over Mariehamn and the countryside of $\AA$ land, but no appreciable damage was sustained.

According to Article Five of the Peace Treaty concluded on Aprii 18, 1947, "the Aland Islands shall remain demilitarized in accordance with the situation as at present existing."12

The garrisoning of troops on the Islands, plus the threat of possible changes in the Autonomy Legislation during the war led the Alanders to ask for increased nationality protection in the years following the war.

The Finnish Parliament complied with the $\AA$ lander request by passing an extended Autonomy Act on December 28, 1951; the 1egislation entered in force on January 1, 1952. The leading principle of the legislation was

That the Alanders themselves should have the right both by legislation and administration to control their own internal affairs within the widest limits possible, subject on1y to the maintenance of the 'unit of Finland as a state,' with special guarantees for the preservation of the population's Swedish language, culture and local customs. 13

Essentially the legislation of 1952 gives increased guarantees for the nationality of the \&landers by providing a special local-cumnational citizenshlp which is known as "\$1and regional citizenship." Residence in the Islands for an unbroken period of at least five years duration is the qualification for that citizenship; application for

12 Mazour, Finland Between East and West, Appendix XI, "Treaty of Peace With Finland", P. 261。

13 Thorvald Eriksson, 1 lands sjH1vstyrelse $i$ kort bversikt (Mariehamn, Finland: Alands Tidnings-Tryckeri Ab., 1964), P。 4. Translated. 
citizenship is made to the $\$ 1$ and Administrative Council after the residence requirement is met. Only those persons having $\$$ land regional citizenship are able to vote in elections or run for positions in the Landsting or the district councils.

There is universal suffrage for $\AA$ land citizens at the age of twenty-one. Regional citizenship is also necessary in order to carry on business or real estate in the Islands. Exceptions are granted only by special permission from the Provincial Administrative Council. Alanders are not subject to such disabilities when they move to the Finnish mainland.

Swedish remains the official language in the province; all instruction in public schools is in Swedish. Finnish may only be used for instruction in a school by the consent of the district where the school is located, or in a private school.

Male \&landers possessing $\AA$ land regional citizenship are exempt from military service, except in the case of a person who moves to the Islands after the age of twelve. Alanders can be drafted for pilot or lighthouse service, but so far no one has been called for those services. The objections raised to conscription in 1939 typify the \&landers' position regarding the demilitarization and neutralization of the Islands in perpetuity, established by the 1921 Aland Convention.

The 1951 Autonomy Legislation can only be altered with the consent of the Aland Landsting.

The Alanders have a single chamber Provincial Assembly, Landsting, which has independent rights to legislate on internal affairs of the province and to regulate the economic life of the province. A Speaker, two Deputy Speakers, and twenty-seven members, all elected for three- 
year terms, constitute the Landsting. The "presidium" of the Landsting is composed of the Speaker and the two Deputy Speakers; they must sign all legislation passed in the Landsting. The Landsting meets approximately sixty days per year; there are two sessions, the Winter Session beginning on March 1, and the Fall Session beginning on No vember 10 .

In practice, such matters as schools, social service, trade, water rights, hunting, fishery, and local communications are regulated by legislation in the Landsting. Measures dealing with constitutional questions, defense, criminal law, the administration of justice, the finances of the republic, and foreign affairs (with some exception), are reserved to the competence of the Finnish Parliament. Foreign agreements entered into by Finland are not applicable to \&land when those agreements deal with matters within the competence of the Aland Landsting, unless agreed to by the Landsting. 14

The legislation by the Landsting may not be vetoed by the suspensive veto of the Finnish President which he exercises in respect to Finnish legislation. He can veto $\AA$ land legislation within three months time only if the Landsting has exceeded its legislative powers under the constitution, or when he considers it in the interests of the internal or external security of the realm to do $80 .{ }^{15}$ otherwise, there are no restrictions on the Aland legislation.

14Thgrvald Eriksson, Âland: An Autonomous Province (Mariehamn, Finland: Alands Tidnings-Tryckeri Ab., 1965), pamphlet.

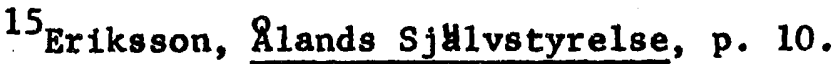


The administration of the province is carried out by the Provincial Executive Council. A Provincial Councillor, Vice-Councillor, and five members compose the Council; they are appointed for three year terms by the Landsting; the Councillor must have the confidence of the Landsting to remain in office. He is the chief civil servant in the province. The functions of the Provincial Executive Council are like those of central government departments, or Ministries. The Council serves in practice as the government and central executive organ of the province. It meets usually two times a week.

Taxes, customs duties, and imposts are collected by the Finnish Republic. The cost of self-government is partially met by an apportionment of the revenue derived from the Islands. By the 1951 Autonomy legislation an Aland Delegation is granted the right to budget and make recommendations to the Finnish Republic concerning the Islands' finances. The Aland Delegation consists of two members appointed by the Finnish government, two members appointed by the Aland Landsting, and a Speaker who is appointed by the Finnish President in agreement with the Speaker of the Aland Landsting. The President of Finland must approve decisions made by the Aland Delegation; in that regard he plays a key role in the system of Aland's self-government.

Besides being an autonomous province, the $\stackrel{\circ}{\mathrm{A}}$ and Islands also constitute a County Administrative District in the Repub1ic of Finland. The territorial limits of the province and the County Administrative District are the same. The county administration is carried on by an Administrative Council headed by a Governor, and a County Administrative Court consisting of three members. 
The Administrative Council deals with tax assessment, automobile taxes, apportionment of taxes among the communal districts, and the collection of taxes; in addition, the Administrative Council administers the penal code of Finland on the Is lands.

The Governor represents the Finnish government in the Islands; he is appointed by the Finnish President after consultation with the Speaker of the $\&$ land Landsting. Failing agreement between the two, the President appoints the governor from a list of five names submitted by the Landsting. The Governor has the duty to open and close the sessions of the $\AA$ land Landsting.

The Administrative Court hears tax appeals, and appeals from communal councils.

Aland has its own flag. It is composed of a blue background with a yellow cross, as the Swedish flag, and a narrower red cross superimposed on the yellow cross. By law, the last Sunday in April is \&land's Flag Day. As a Nordic cross flag, it symbolizes \&land's ties with the Scandinavian region.

1 land, as an autonomous province in the Republic of Finland, has indeed a unique position. Operating almost as a state within a state, the machinery for legislation, administration, and financing apply to roughly 21,500 persons. 
CHAPTER VIII

\section{CONCLUSIONS}

The \&land Archipelago constitutes a region where international attention has been focused in historical and in more recent time.

A primary focus is naturally the status of the Rland Islands established by international agreement and guarantee which is still in effect through the assumption, by the United Nations, of continuing international agreements concluded under the auspices of the League of Nations .

It is safe to conclude that the importance accorded to the \&land Islands by the League Council Resolution of June 24, 1921, and the Geneva Convention of October 22, 1921, would not have been recognized had the $\AA 1$ and Islands not been a point of interest in diplomatic circles during the preceding centuries.

The negotiations for a definitive settlement came after previous suggestions and agreements had not withstood the trial of experience. Whether the 1921 Convention is adequate for late twentieth century crises remains to be seen. The Convention was sufficiently flexible to allow planning for joint Swedish-Finnish defense in the projected Second World War; but that flexibility was viewed by the Alanders as a weakness in the arrangement. By the actual terms of the Convention, no provision was made for official modification, but the signatories who agreed to partial revision of the Convention in 1939 did not consider the Convention 
thus abrogated.

Obviously the Alanders do not wish to become embroiled in international power struggles. At the present; the neutral tendencies of both Finland and Sweden do provide at least a framework in which $\AA$ land's condition of neutralization can exist during peacetime. Changes in weapons, technology, and defense planning may again involve the Islands in a situation where their status is compromised.

The \&landers seem at once extremely trusting in the rule of law, yet aware of their size and influence. Proposed arrangements for the Stockholm Plan in 1939 revealed their position. In the words of one Alander, Matts Dreijer,

There have always been and always will be differences between the great and the sma11, even in the family of nations. But the vital interests of the small are too often overlooked by the great. That was the case with the negotiations for the fortifications. Then Finf and and Sweden assumed the role of the large powers and the Alanders' only defense was in their laws and in the strength of the provisions of international 1 aw. 1

The 1921 League Council resolution established that the Alanders' Swedishness, "svenskhet," was to be guaranteed, and opened the way for the Council to recommend measures to be taken "a l'interieur" in Finland

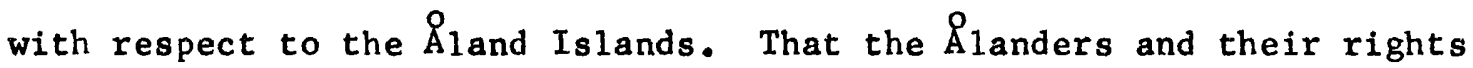
may be expendable is not a thought they would 11ke to admit.

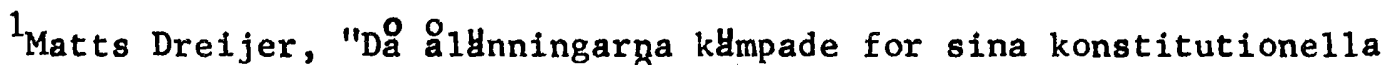
rHttigheter," SHrtryck ur tidningen Aland, nr.9-1965, p. 20. "Det har alltid varit och kommer alltid att vara skillnad pă stora och smă, Hven i staternas familj. Men de smås livsviktiga intressen furbises alltf $\mathrm{f}$ ofta av de stora. S\& var det n 4 ra att $g \&$ med $\& 1$ and under befllstningsfHrhandingarna. HHr spelade Finland och Sverige rollen sQsom de stora och alynningarnas enda vHrn var deras $i$ lag och i internationella domslut befHsta ruttigheter." 
The machinery set up for legislation, administration, and financing is perhaps elaborate when it in reality applies only to some 21,500 persons, a small percentage of the total Swedish-speaking minority in the Finnish Republic. The unique autonomous position of the Islands within Finland provides a focus for the consideration of the Aland question.with emphasis on domestic arrangements in force.

The focus on domestic arrangements illustrates ascase where one province of a nation enjoys an unprecedented degree of autonomy with apparent success. The continuing preservation of the population's "svenskhet" can be attributed to the peoples' own desire to avoid being "fennicized," and to the legal provision that no alteration of the autonomy laws may be changed without the consent of the $\AA$ land Landsting, even though the Finnish Parliament was the originator of the Autonomy Legislation.

The operation of \&land's Autonomy can be viewed as an example of extreme protection for a minority which operates effectively, given the Alanders concern for nationality, and respect for provincial, state, and international law. It is probably safe to conclude that such an arrangement has a good chance of success in the Scandinavian area where there exists a kind of inexplicable compulsion to observe and protect legal agreements, with recourse to armed conflict among the Scandinavians being the very last option chosen during disputes. The dissolution of Sweden-Norway in 1905 and the solution of the 81 and dispute attest to the potential for peaceful settlement between nations in Scandinavia. The practices of cooperation and moderation in the Scandinavian democracies along with expressed concern for citizends welfare are important advantages present in the case of the \&land Islands. 
If the question were asked, can the same type of settlement be applied to another similar case in another area, the answer is probably "no." The setting of the \&1and Islands between Finland and Sweden is quite unique; the neutrality espoused and practiced by Sweden and Finland as a neighbor to the Soviet Union calls for a special kind of balanced restraint.

Norwegian and Danish membership in NATO decreases the room for maneuvering left to Sweden and Finland in the Baltic and North Atlantic area. Swedish and Finnish consciousness of the role as "bridge" or "barrier" to the Soviet Union is thus increased.

The Swedish role in foreign policy has for several centuries been geared to ensuring a Swedish position of strength not based on policies of expansion, in contrast to her expansion and empire in the era of Sweden as a "great power."

In the light of rising defense costs, it does not seem likely that Sweden would again press for possession of the $\AA$ land Islands, especially given the satisfaction of the \&landers with their status. Also, the Islands' strategic value may have diminished in the last decades given present long-range weapons and aircraft capabilities, as well as more sophisticated underwater vessels.

At the present time, the hottest crisis spots in international politics do not include the Northern Baltic Sea. The isolation of the \&land Islands from crises is a point in favor of the status quo.

At the same time there are no indications of great power interests in changing the status quo. The voice of the Soviet Union, raised in the 1961 letter to Finnish President Kekkonen over changes in NATO command 
organization, and in 1966 over the NATO expeditionary force operation "Winter Express" in Norway, does not now advocate a change in the Islands' status. Maintenance of the present status is an indication of the functioning of the "Nordic Balance."

In conclusion, present conditions seem to favor the maintenance of the status quo of the \&land Islands, both nationally and internationally. Possible changes would evoke responses from the \&landers, Finns, Swedes, Soviets, as well as from the NATO powers. The past importance of the Islands would In that case have to be reconsidered. Reactions to possible changes might well be hampered by previous assumptions as to the role the Islands play in the Baltic.

In any case, the aspects of the question here considered would again arise and serve as factors influencing future arrangements. 
CARTE DES NLES; D A ALAND

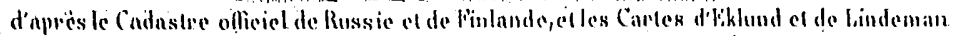

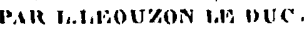

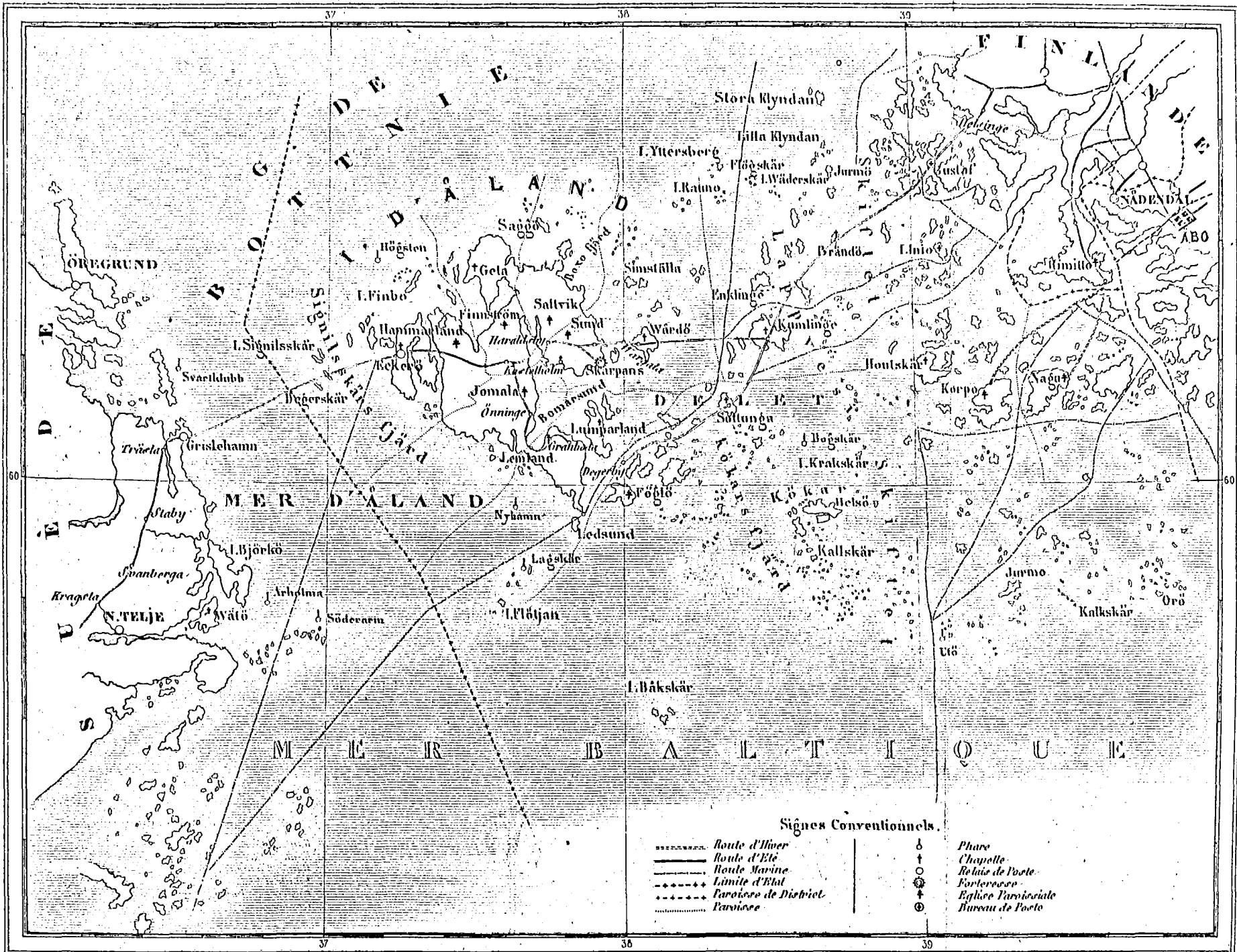

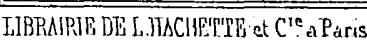

thin

Figure 1. Map of the $\AA$ land Islands, 1854. in Louis A. Leouzon 1e Duc, Les 1les d'\&land (Par18: Hachette, 1854). 


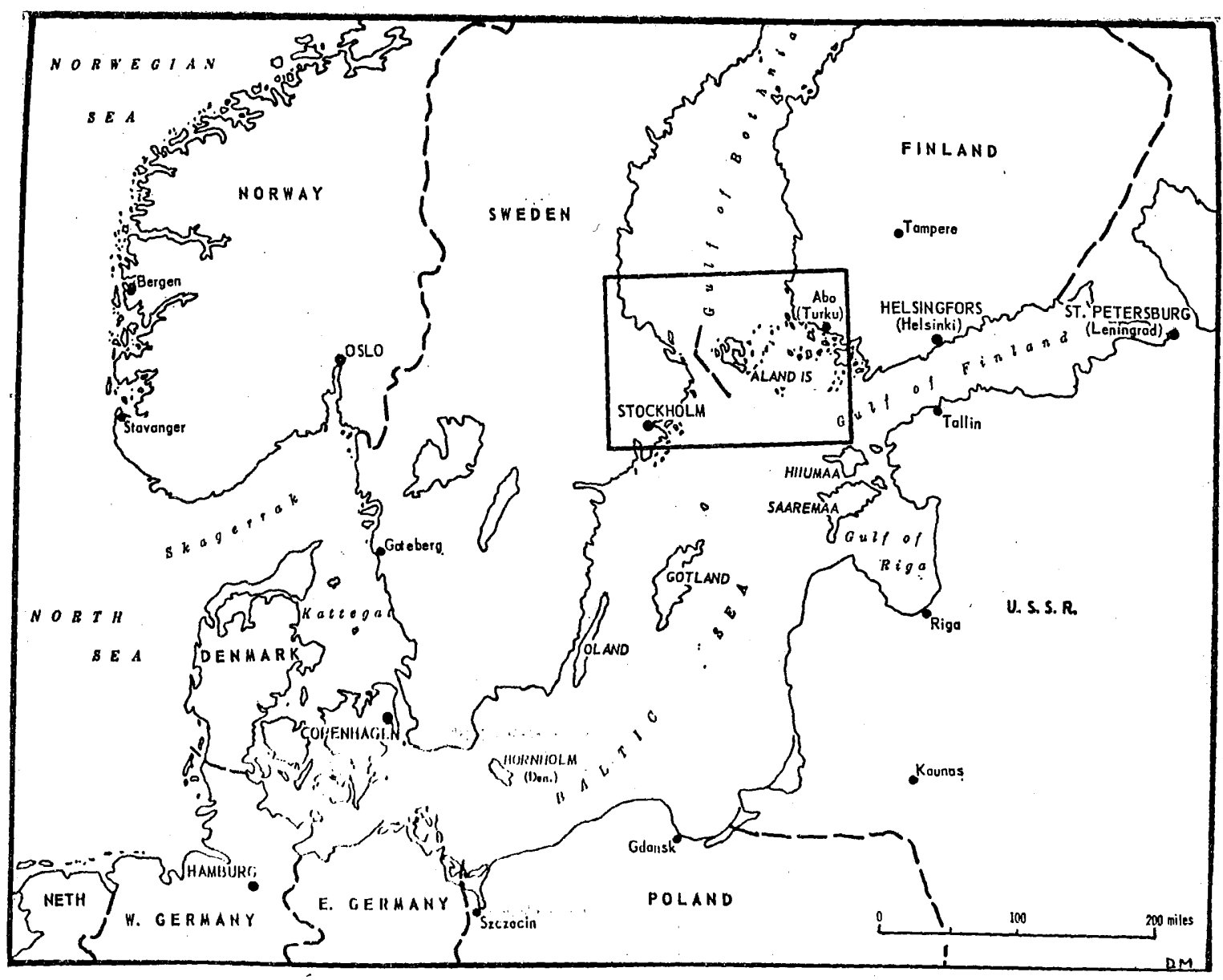

Figure 2. Map of the Approaches to the \&land Islands, in James Barros, The Aland Islands Question: Its Settlement by the League of Nations. (New Haven: Yale University Press, 1968). P. 9. 


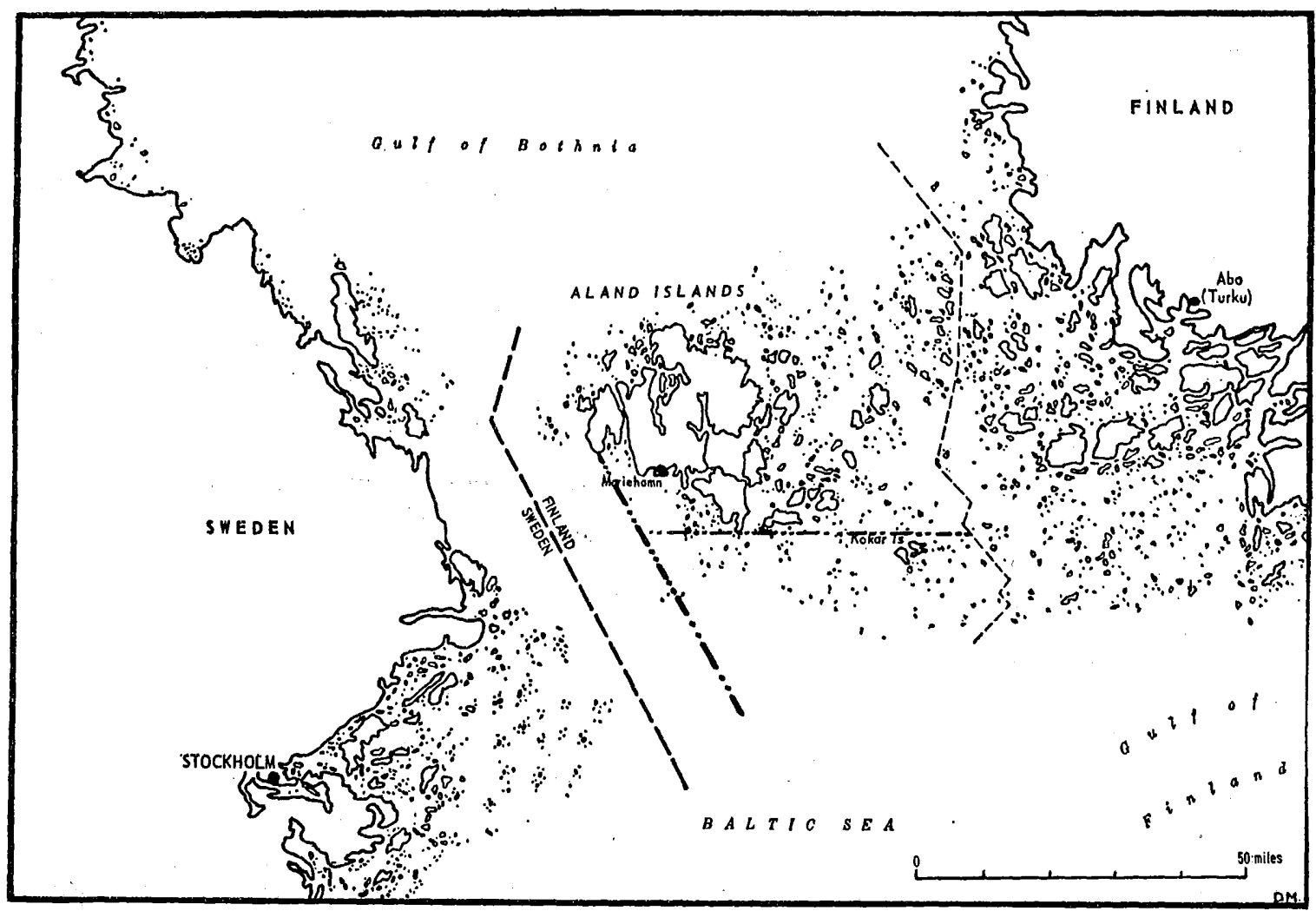

Southern and Western borders proposed in the 1939 Stockholm Plan.

Figure 3. Map of the $\AA$ land Islands, showing the Zone borders revised in the 1939 Stockholm Plan, modified from James Barros, The Aland Islands Question: Its Settlement by the League of Nations (New Haven: Yale University Press, 1968), p. 40 The area South of the horizontal line was to be jointly fortified by Sweden and Finland and the area North of the horizontal line to remain demilitarized and neutralized; the area West of the $\mathrm{NW}-\mathrm{SE}$ line was to be defended by Sweden. 
A LIST OF WORKS CONSULTED

"Ahvenanmaa," Encyclopaedia Britannica. 1968 ed. Vol.I.

Andrên, Nils. Power Balance and Non-Alignment: A Perspective on Swedish Foreign Policy. Stockholm: Almqvist and Wiksell, 1967.

Barros, James. The Aland Islands Question: Its Settlement by the League of Nations. New Haven: Yale University Press. 1968.

Bouillet, M. N. (ed.) Dictionnaire universel d'Histoire et de Géographie. Paris: Hachette, 1861.

Brown, Philip Marsha11. "The Aaland Islands Question," American Journal of International Law, XV, No. 2 (April, 1921), 268-272.

Dean, Vera Micheles. Europe in Retreat. New York: Alfred A. Knopf,

Dreijer, Matts. "Då O̊länningarna klmpade fHr sina konstitutionella rHttigheter," Sätryck ur tidningen \&land nr。9-1965.

Dreijer, Matts. Glimpses of \&land History. Mariehamn, Finland: Alands Tidnings-Tryckeri Ab., 1968.

Eriksson, Thorvald \$land: An Autonomous Province. Mariehamn, Finland: Alands Tidnings-Tryckeri Ab., 1965, pamphlet.

Eriksson, Thorva1d \&lands sjulvstyrelse $i$ kort yversikt. Mariehamn, Finland: Alands Tidnings-Tryckeri $\mathrm{Ab}_{0}, 1964$.

Florinsky, Michael T. Russia: A History and an Interpretation, Vol. I and II. New York: The MacMillan Company, 1966.

Gih1, Torsten. Den Svenska Utrikespolitikens Historia Vol. II. Stockholm: P. A. Norstedt och SUners FUrlag, 1951.

Great Britain. Foreign Office Historical Section Handbooks, The \&land Islands. London: H. M. Stationery Office, 1920 .

Gregory, Charles Noble. "The Neutralization of the Aaland Islands," American Journal of International Law XVIII, No. I (January, 1923), 63-76.

Howard, Sir Esme. The Theatre of Life, Vol. II Boston: Little, Brown and Company, 1936. 
Jackson, J. Hampden. Finland. New York: The MacMillan Company, 1940.

Jones, S. S. The Scandinavian States and the League of Nations. Princeton: Princeton University Press, 1939.

Jutikkala, Eino. A History of Finland. Translated by Paul Sjbblom, New York: Frederick A. Praeger, 1962.

Kivikoski, E1la. Finland. Translated by Alan Binns, New York: Frederick A. Praeger, 1967.

LEouzon le Duc, Louis A. Les iles d'\&1and. Paris: Hachette, 1854.

Mannerheim, Kar1 Gustav. The Memoirs of Marshal Mannerheim. Translated by Count Eric Lewenhaupt, New York: E. P. Dutton and Company, Inc., 1954 .

Mazour, Anatole G. Finland Between East and West. Princeton: D. Van Nostrand Company, Inc., 1956.

Mead, W. R. An Economic Geography of the Scandinavian States and Finland. London: University of London Press, 1958.

Meinander, Ragnar. "Protection of Minority Rights in Finland," Finnish Features No. 4, 1965, Helsinki: Ministry of Foreign Affairs.

Oakley, Stewart. A Short History of Sweden. New York: Frederick A。 Praeger, 1966.

O'De11, Andrew C. The Scandinavian World. London: Longmans, Green and Co., 1957.

Padelford, Norman J., and Andersson, K. G8sta A. "The Aaland Islands Question," American Journal of International Law, XXXIII, No. 3 (Ju1y, 1939), 465-487.

P1att, Raye R。(ed。) Finland and Its Geography. New York: Due11, Sloan, and Pearce, 1955.

Seignobos, Charles. A Political History of Europe. Translation edited by S. M. Macvane. New York: Henery Holt and Company, 1899.

Shearman, Hugh. Finland: The Adventures of a Sma11 Power. New York: Frederick A. Praeger, 1950 .

Smith, C. Jay. Finland and the Russian Revolution: 1917-1922. Athens, Georgia: The University of Georgia Press, 1958.

Sbderhjelm, J. 0. Démilitarisation et neutralisation des Ples d'Aland en 1856 et 1921. Helsingfors, 1928 . 
S bmme, Axel. A Geography of Norden: Denmark, Finland, Iceland, Norway, Sweden. Os10: J. W. Cappelens FBr1ag, 1960 .

Tingsten, Herbert. The Debate on the Foreign Policy of Sweden: 19181939. Translated by Joan Bulman, London: Oxford University Press, 1949.

Toivola, Urho. Introduction to Finland: 1960. Porvoo, Finland:

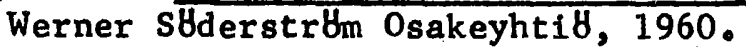

Wuorinen, John H. A History of Finland. New York: Columbia University Press, 1965 .

Wuorinen, John $\mathrm{H}_{0}$ Scandinavia. Englewood Cliffs, New Jersey: PrenticeHa11, Inc., 1965.

\section{DOCUMENTS}

League of Nations, Covenant of the League of Nations, January 10, 1920.

Mazour, Anatole G. Finland Between East and West. Princeton: D. Van Nostrand Company, Inc., 1956. Appendix I and XI, Pp. 209226, 260-279.

"Treaty of Peace between the Republic of Finland and the Russian Socialist Federative Soviet Republic." Signed on October 14, 1920, Dorpat, (Tartu) Estonia.

"Treaty of Peace with Finland." Signed in Paris, February 10, 1947, between the Union of Soviet Soclalist Republics, the United Kingdom of Great Britain and Northern Ireland, Australia, the Byelorussian Soviet Socialist Republic, Canada, Czechos1ovakia, India, New Zealand, the Ukrainian Soviet Socialist Republic, the Union of South Africa, and Finland.

sbderhjelm, J. 0. Démilitarisation et neutralisation des Iles d'Aland en 1856 et 1921. Helsingfors: 1928. Pièces justificatives, pp. 341-343, 347-378.

"Accord relatif la mer Baltique," signe à Saint-Petersbourg 1 e $10 / 23$ avri1 1908 .

"Convention relative à la non-fortification et la neutralisation des Iles d'Aland" (1e 20 octobre 1921).

"Deuxième avant-projet finlandais."

"Deuxième avant-projet suedois."

"Motifs du deuxtème avant-projet finlandais." 
"Premier avant-projet finlandais."

"Premier avant-projet suédois."

"Rapport de la Commission Internationale de juristes chargée par le Conseil de la Societé des Nations de donner un avis consultatif sur les aspects juridiques de la question des Iles d'Aland," (1e 5 september 1920).

"Traite de paix entre 1'Autriche, la France, la Grande-Bretagne, La sardigne et la Porte Ottomane, signe a Paris le 30 mars 1856: Article 33, Annexe II.

"Troisième avant-projet suédois."

\&lands Lagsamling: 1964. (ed.) Martien Isakson, Rolf Sundman, Sune Carlsson. Mariehamn, Finland: $\AA$ lands Tidnings-Tryckeri Ab., 1964 . 